\title{
YARGILAMAYI HIZLANDIRAN BİR MODEL OLARAK ALMAN CEZA MUHAKEMESI HUKUKUNDA HÜKÜM ANLAŞMASI (§257c StPO)
}

\author{
NEGOTIATED AGREEMENT IN GERMAN CRIMINAL PROCEDURE LAW AS A TRIAL \\ ACCELERATING MODEL ( $\$ 257 \mathrm{c} \mathrm{StPO)}$
}

\author{
Meral EKİCI ŞAHİN* ${ }^{*}$ (iD)
}

Makale Bilgi

Gönderilme: 22/01/2020 Kabul: 04/06/2020

\section{Anahtar Kelimeler}

Ceza Muhakemesi

Hukuku,

Hüküm Anlaşması,

Ceza Pazarlığ l,

Ikrar,

Anlaşmanin

Bağlayıcıliğg,

Seri Muhakeme

Usulü.

\section{Article Info}

Received: 22/01/2020 Accepted: 04/06/2020

\section{Keywords}

Criminal Procedure Law,

Negotiated Agreement, Punishment Negotiation, Confession,

Binding Force of The

Agreement,

Rapid Trial Procedure.
Özet

Alman ceza muhakemesi hukukunda 1970'li yıllardan bu yana, yargılamanın hızlandırılması ve mahkemelerin iş yükünün azaltılması yönünde genel bir eğilim bulunmaktadır. Bunun sonucunda, yeni ceza muhakemesi hukuku kurumları ortaya çıkmıştır. Bu kurumlardan biri de uygulamada uzun süredir mahkemelerin rutuni haline gelmiş olan, ancak 2009 yılında Alman Ceza Muhakemesi Kanunu §257c'de yapılan düzenlemeyle yasal zemine kavuşan hüküm anlaşmasıdır. Türk ceza muhakemesi hukukunda da yargılamayı hızlandırmak amacıyla, Ceza Muhakemesi Kanununda "seri muhakeme usulü" (TCMK m.250) ve "basit yargılama usulü" (TCMK m.251) gibi yeni kurumlar düzenlenerek, Ceza Muhakemesi Kanununa eklenmiştir. TCMK m.250'yi yeniden düzenleyerek "seri muhakeme usulü" getiren 7188 sayılı Kanun'un 23. maddesinin gerekçesinde: "maslahata uygunluk" ilkesinden daha geniş bir biçimde istifade edilmeye başlanan Alman hukukunda, günümüzde Alman Ceza Usul Kanununun 257 c maddesinde yer alan şekliyle "mahkeme ve muhakeme süjeleri arasında anlaşma" adı altında, sanığın suçunu kabul etmesi durumunda uygulanan bir muhakeme usulü bulunmaktadır", şeklinde bir açıklamaya yer verilmiştir. Ayrıca seri muhakeme usulünün düzenlenmesinde Almanya'nın modellendiğinden de söz edilmiștir. Bu nedenle hüküm anlaşması kurumu dikkatimizi çekmiştir. Bu çalışmada, ceza muhakemesini hızlandırma çabalarına katkı sağlamak amacıyla, AlCMK §257c'de düzenlenmiş olan "hüküm anlaşması" kurumu incelenmiştir.

\begin{abstract}
Since 1970s, there has been a tendency to accelerate the proceedings and to reduce the workload of the courts in German criminal procedure law. As a result, new criminal procedure law concepts have emerged. One of these concepts is the provision of the Negotiated Agreement which has long been the routine of the courts in practice, but got the legal basis in 2009 with the German Criminal Procedure Code (StPO) \$257c. In order to accelerate the proceedings in the Turkish criminal procedure law, new regulations such as "rapid trial procedure" (CMK m.250) and "simple trial procedure" (CMK m.251) were introduced in the Criminal Procedure Code (CMK). The reasoning of the amendment in article 23 of the Code numbered 7188, which re-regulates the CMK m.250 and brings the "rapid trial procedure", mentions StPO $\$ 257 \mathrm{c}$ because of the similarity. In this study, the concept of the "Negotiated Agreement", which is regulated in the StPO $\$ 257 \mathrm{c}$, is examined in order to contribute to the efforts to accelerate the criminal procedure.
\end{abstract}




\section{I.GİRIŞ}

Hüküm anlaşması, Alman ceza muhakemesi hukukunda muhakemenin hızlandırılması amaciyla 1970'lerden itibaren mahkemeler tarafından geliştirilmiş ve fiilen uygulanmış bir kurumdur $^{1}$. Modelin esası mahkeme, savcılık ve savunma makamlarının anlaşmasıdır. Anlaşmanın şartları; sanığın suçunu ikrar etmesi, bunun karşılığında mahkemenin hükmedeceği cezada önemli bir indirim yapmasıdır. Hüküm anlaşması uzun yıllar boyunca çoğu zaman gizlice, duruşma salonu dişında yapılmış, hatta duruşmalarda böyle bir anlaşmanın varlığından çoğu zaman hiç söz edilmemiş, anlaşma duruşma tutanaklarına yansıtılmamıştır. Ancak sanık suçunu ikrar edip, mahkeme yeni delil ikamesinden feragat ettiğinde ${ }^{2}$, taraflar arasında bir anlaşma olduğu ortaya çıkmıştır.

1982 yılında takma isimle yayınlanan bir makale, dikkatleri bir anda bu konuya çekmiştir ${ }^{3}$. Böylece hüküm anlaşması (Verständigung) ${ }^{4}$, Alman ceza muhakemesi hukukunun en tartışmalı konularından biri haline gelmiştir. Öğreti hüküm anlaşmasına karşı eleştirel ve mesafeli yaklaşırken ${ }^{5}$, Alman mahkemeleri kurumu uygulamaya ve geliştirmeye devam etmişlerdir ${ }^{6}$.

Federal Alman Mahkemesi daireler kurulu, 2005 yılında verdiği bir kararda ${ }^{7}$, kural olarak hüküm anlaşmasını yasaklayan bir düzenleme bulunmadığına, ancak böyle bir anlaşma yapılırken Anayasal sınırlara özenle riayet edilmesi gerektiğine işaret etmiştir. Uygulamada çok sevilen ve sık sık başvurulan hüküm anlaşması, 4.8.2009 tarihinde yürürlüğe giren kanunla, yasal zemine kavuşmuştur. AlCMK $\$ 257 \mathrm{c}$ 'de yer alan hüküm anlaşmasına ilişkin düzenlemenin Alman Anayasasına aykırı olduğu iddiasıyla Alman Anayasa Mahkemesine başvurulmuştur. Başvuruyu inceleyen Alman Anayasa Mahkemesi, 2013 yilında AlCMK §257c'nin Alman Anayasasina aykırı olmadığına karar vermiştir ${ }^{8}$. Kararın gerekçesinde, hüküm anlaşmasının mahkemenin maddi gerçeği araştırma yükümlülügünü ortadan kaldırmadığına, anlaşmanın hükmün tek dayanağı olamayacağına, mahkemenin hüküm kurarken sanığın suçluluğu konusundaki bütün şüpheleri yenmek zorunda olduğuna, bu nedenle sanık suçunu ikrar etmiş olsa bile, mahkemenin bu ikrarın gerçeğe uygunluğunu denetlemesi gerektiğine işaret edilmiştir. AlCMK §257c'nin hukuka uygun bir hüküm anlaşmasının geçerlilik şartlarını belirlediği, geçersiz olanın ise yasal çerçeveye uymayan informel anlaşmalar olduğuna Alman Anayasa mahkemesinin 2 dairesinin verdiği bu kararda vurgulanmıştır. Hüküm anlaşmasıyla kanun koyucunun rızaya dayanan yeni bir muhakeme modeli getirmediği, bilakis anlaşmayı mevcut ceza muhakemesi sistemine entegre ettiği belirtilmiştir ${ }^{9}$. Mahkeme, hüküm anlaşmasına ilişkin yasal düzenlemenin, uygulamaya ilişkin önemli eksiklikleri bulunsa da bu haliyle Alman Anayasası'na aykırılık teşkil etmediğini belirtmiştir. Bununla birlikte kanun koyucunun anayasal güvenceleri sağlamak için gerekli kontrol ve iyileştirme mekanizmalarını kurması gerektiğine de işaret edilmiştir ${ }^{10}$.

AlCMK §257c'ye göre; mahkeme, vereceği hüküm konusunda yargılamanın taraflarıyla bir anlaşma yapabilir. Mahkeme ile muhakeme süjeleri arasında anlaşma başlığını taşıyan AlCMK $§ 257 \mathrm{c}$ şu şekildedir:

1. Mahkeme, uygun hallerde, aşağıdaki fikralarda öngörülen şartlarda, muhakeme süjeleriyle muhakemenin ilerleyişi ve neticesine ilişkin olarak anlaşma yapabilir. §244/2 hükmü saklıdır.

\footnotetext{
${ }^{1}$ ROENNAU, Thomas, “Grundwissen: Strafprozessrecht: Verständigug im Strafverfahren”, JuS 2018, s.114-115.

${ }^{2}$ ROENNAU, JuS 2018, s.115.

${ }^{3}$ DEAL, Detlef, aus Mauschelhausen, "Der strafprozessuale Vergleich”, StV 1982, H. 11, s.545- 552.

${ }^{4}$ Muhakemenin taraflarının muhakeme dışında, kapalı kapılar ardında ve herhangi bir hukuk kuralıyla bağlı olmaksızın anlaşma yapması öğretide hüküm pazarlığı yani "Deal" olarak adlandırılmaktadır. "Verständigung" ise duruşma salonunda, aleni olarak ve kanunda şartları ve sınırları belirlenmiş olan usulle mahkemenin, savcı ve sanıkla anlaşma yapmasını ifade eder. Bu açıdan "Deal" yasadışı hüküm pazarlığı, "Verständigung" ise hukuka uygun anlaşma anlamında kullanılmaktadır.

5 Öğretide, hüküm anlaşması "hukuk devleti ilkesine dayanan ceza muhakemesini" topyekün erozyona uğrayacağ gerekçesiyle eleştirilmektedir. Bkz. ROXIN, Claus/ACHENBACH, Hans/JAEGER, Christian/HEINRICH, Manfred: Strafprozessrecht, 17. Aufl, München 2019, s.152.

${ }^{6}$ BGHSt 36, s.210-216; BGHSt 42, s.191-195.

${ }^{7}$ BGHSt 50, s.40- 64 .

${ }^{8}$ BVerfG, Urt. v. 19.3.2013, 2 BvR 2628/10, 2. BvR 2883/10, 2BvR 2155/11, in: NJW 2013, s.1058- 1071.

${ }^{9}$ BVerfG, Urt. v. 19.3.2013, 2 BvR 2628/10, 2. BvR 2883/10, 2BvR 2155/11, in: NJW 2013, s.1058- 1059.

${ }^{10}$ BVerfG, Urt. v. 19.3.2013, 2 BvR 2628/10, 2. BvR 2883/10, 2BvR 2155/11, in: NJW 2013, s.1058.
} 
2. Anlaşma yalnızca hüküm ve ara kararların içeriği, muhakemeye ilişkin diğer tedbirlerle muhakemeye katılan tarafların davranışlarına ilişkin olabilir. Her anlaşmanın temel unsuru, ikrar olmalıdır. Kusuru tespit eden kararla, güvenlik tedbirleri konusunda anlaşma yapılamaz.

3. Mahkeme, anlaşmanın içeriğinin nasıl olabileceği konusunda bilgilendirme yapar. Bunun yanında mahkeme, somut olayın bütün özelliklerini ve cezanın belirlenmesine ilişkin genel kuralları dikkate alarak, cezanın alt ve üst sınırını da açıklayabilir. Muhakeme süjeleri görüşlerini bildirme olanağına sahiptir. Sanık ve savcılık mahkemenin yaptığı teklifi kabul ederse, anlaşma sağlanmış olur.

4. Hukuki veya maddi açıdan önemli olan hususlar mahkemenin gözünden kaçar veya bu hususlar sonradan ortaya çıkarsa ve mahkeme bu nedenle önerdiği ceza aralığının fiille ve failin kusuruyla orantılı olmadığı kanaatine ulaşırsa, mahkemenin anlaşmayla bağlılığı son bulur. Sanı̆̆ın muhakemenin devamındaki davranışları, mahkeme tarafından kendisinden beklenen davranışlarla çeliştiğinde de bu hüküm uygulanır. Bu durumda, sanığın ikrarı kullanılamaz. Mahkeme kararını değiştirdiğini gecikmeksizin bildirmek zorundadır.

5. Sanık, 4. fikrada öngörülen neticelerden mahkemenin anlaşmadan caymasının şartları ve caymanın sonuçları konusunda bilgilendirilmelidir.

Davaların kısa sürede sonlandırılması ve ceza muhakemesinin hızlandırılması amacıyla yapılan bu düzenleme, ceza muhakemesine hakim olan temel ilkelere aykırılık teşkil ettiği iddiasıyla eleştirilse de, uygulama açısından artık vazgeçilmez bir kurum haline gelmiştir ${ }^{11}$. Hüküm anlaşması lehinde ve aleyhinde ileri sürülen görüşler aşağıda açıklanmıştır.

\section{HÜKÜM ANLAŞMASI LEHİNDE VE ALEYHIINDE GÖRÜŞLER}

\section{A. Lehe Görüşler}

Hüküm anlaşması lehinde ileri sürülen görüşler şu şekildedir:

a. Hüküm anlaşmasıyla uzun ve zahmetli ceza muhakemesi süreci hızlandırılır ve uyuşmazlıklar kısa sürede sonlandırılır. Hüküm anlaşmasıyla yeni delil araştırma ve ispat süreçlerine gerek kalmaz, bu süreçlerden vazgeçilir. Böylece hüküm anlaşmasıyla hem zamandan hem de mahkeme masraflarından tasarruf edilir. Bu açıdan hüküm anlaşması, usul ekonomisine ve "çabukluk" ilkesine uygun bir kurumdur"

Hüküm anlaşması, özellikle ekonomik suçlarda önemli bir işlevi yerine getirmektedir ${ }^{13}$. Ekonomik suçlarda somut olay, hukuki açıdan çoğu zaman kapsamlı ve karmaşık olduğundan, yargılamada ilerleme sağlanamamakta; mahkemeler yıllarca duruşmalarla meşgul olmasına rağmen, taraflar açısından tatmin edici bir sonuca ulaşmak çoğu zaman mümkün olmamaktadır. Uzayan davalarda adalet çoğunlukla sağlanamadığından, klasik "ceza muhakemesi” kendisinden beklenen fonksiyonu icra edememektedir ${ }^{14}$.

b. Hüküm anlaşması, AİHS m.6 ile garanti altına alınmış olan adil yargılanma hakkına aykırılık teşkil etmez. Bilakis sanığa muhakeme sürecine etki edebilme imkânı vererek, sanığın ceza muhakemesindeki pozisyonunu güçlendirir ${ }^{15}$. Ancak bunun için AlCMK $\$ 257 \mathrm{c} / 5$ 'de düzenlenen sanığa haklarının belletilmesi konusundaki kurallara yani sanığın aydınlatılmasına, özenle riayet edilmelidir ${ }^{16}$.

c. Hüküm anlaşması zamanın ruhuna uygun bir kurumdur. Uyuşmazlıkların anlaşma yoluyla çözümlenmesine ilişkin yöntemler bütün dünyada öne çıkmaktadır. Barışçıl yöntemler sayesinde sosyal ve hukuki barış güçlenmektedir ${ }^{17}$.

d. Sanı̆̆ın ikrarı, tanık dinlenmesi veya başka delil araştııılmasını gereksiz kıldığından, özellikle cinsel suçlarda mağdurun tekrar tekrar dinlenmesi veya muayeneye gönderilmesi

\footnotetext{
${ }^{11}$ KREY, Volker/HEINRICH, Manfred: Deutsches Strafverfahrensrecht, 2. Aufl., Stuttgart 2019, kn. 1511.

12 KREY/HEINRICH, kn. 1507.

${ }^{13}$ BEULKE, Werner/SWOBODA, Sabine: Strafprozessrecht, 14. Aufl., Heidelberg 2018, kn. 394.

${ }^{14}$ VOLK, Klaus/ENGLAENDER, Armin: Grundkurs StPO, 9. Aufl., München 2018, §30, kn. 2.

${ }^{15}$ BVerfG, NJW 2013, s.1060 vd.

${ }^{16}$ GOETTGEN, Martin: Prozessökonomische Alternativen zur Verständigung im Strafverfahren, Berlin 2019, s.17.

${ }^{17}$ KREY/HEINRICH, kn. 1507.
} 
söz konusu olmayacak, böylece mağdur yaşadığı travmayı yeniden yaşamak zorunda kalmayacaktır ${ }^{18}$. Bu açıdan da hüküm anlaşması mağduru koruyan bir işleve sahiptir.

\section{B. Aleyhe Görüşler}

Hüküm anlaşması aleyhinde aşağıdaki görüşler ileri sürülmüştür.

a. Hüküm anlaşması, masumiyet karinesine aykırıdır ${ }^{19}$. Hüküm anlaşmasında, AlCMK §136a'da gösterilen yasak sorgu yöntemleri kapsamında değerlendirilebilecek yoğunlukta bir baskıdan söz edilemese de sanık ağır ceza tehdidi ve beraat etme ihtimali arasında sıkışır. Sanık susma hakkını kullanarak kendi aleyhine beyanda bulunmaktan kaçınabilir. Ancak bu durumda, ağır ceza tehdidiyle karşı karşıya kalır ${ }^{20}$. Bu da sanık üzerinde, suçu ikrar etme konusunda bir baskı yaratır. Sanık ağır ceza tehdidinden kurtulmak istiyorsa, suçunu ikrar etmelidir. Suçunu ikrar ettiğinde ise, muhakeme sonunda beraat etme ihtimali ortadan kalkar ${ }^{21}$. Uygulamada, sanığa anlaşma yapmasını kimi zaman bizzat kendi müdafii tavsiye etmektedir. Sanık içinden çıkılması zor bir ikileme düşmektedir. Bu durum masumiyet karinesini ihlal eder, sanığı psikolojik bask1 altına sokar ve onu muhakemenin objesi ${ }^{22}$ haline dönüştürür. Bu nedenle mahkeme sanığa suçunu itiraf ederse cezasında indirim yapılacağı, itiraf etmezse en ağır şekilde cezalandırılacağı gibi bir teklifle gelmemeli veya suçunu itiraf etmesi halinde kendisine hukuka aykırı bir menfaat temin edileceği vaadinde bulunmamalıdır. Böyle bir anlaşma, AlCMK §136a kapsamında yasak sorgu yöntemlerine girer ve hukuka aykırıdır ${ }^{23}$.

Masumiyet karinesi şeklen yürütülen bir ceza muhakemesiyle aşılamaz. Suçluluğu ispat edilinceye kadar, herkes masumdur. Hukuka uygun bir muhakeme neticesinde suçluluğu ispat edilmeden, kimseye ceza verilemez. Hukuka uygun bir yargılama yapılmadan kişinin suçluluğu konusunda hüküm kurulamaz ${ }^{24}$. Sanığın masumiyetine ilişkin şüphe, ancak şüpheden sanığın yararlanacağı (in dubio pro reo) ve kimsenin kendi aleyhine delil göstermeye zorlanamayacağ (nemo- tenaturse ipsum accusare) ilkelerine riayet edilerek yapılan bir yargilama neticesinde yenilebilir $^{25}$. Bu iki ilkeye riayet edilmeden yapılacak bir yargılamada, masumiyet karinesinin çürütülmesi ve sanığın suçluğu konusunda vicdani bir kanaate ulaşılması mümkün değildir. Hüküm anlaşmasında ise, ağır cezaya mahkum olma tehdidiyle karşı karşıya kalan sanık, bu tehditten kurtulmak için suçunu ikrar eder. Bu durum sanığın irade özgürlüğüne ve kendi aleyhine delil göstermeye zorlanamayacağı ilkesini aykırıdır²6.

b. Hüküm anlaşması kovuşturma mecburiyeti ilkesine aykırıdır ${ }^{27}$. Zira bir suçu takibe yetkili makamlar yani savcı ve ona bağlı olarak çalışan kolluk kuvvetleri, bir suçun işlendiğini öğrendiklerinde, derhal işin aslını araştırmak zorundadır. Bu araştırma neticesinde; fiil ve fail tespit edilir, kamu davasının açılmasına yetecek ölçüde delil elde edilir ve dava şartları gerçekleşirse savcı, iddianame düzenleyerek kamu davasını açmak ve muhakeme sonuçlanıncaya kadar davayı takip etmekle görevlidir ${ }^{28}$. Bu şekilde; suçu takibe yetkili makamlar tarafindan derhal soruşturma evresine başlanmasını ifade eden "araştırma mecburiyeti", yeterli delile ulaşılması ve şartların gerçekleşmesi halinde kamu davası açılmasını ifade eden "kamu davasını açma mecburiyeti" ve açılan kamu davasının muhakeme sonuçlanıncaya kadar yürütülmesini ifade eden "kamu davasını yürütme mecburiyeti" alt ilkelerinden oluşan ilkeye "kovuşturma

\footnotetext{
${ }^{18}$ KREY/HEINRICH, kn. 1507.

${ }^{19}$ DUTTGE, Gunnar: "Die Urteilabsprachen als Signum einer rechtlichen Steuerungskriese", in: Festschrift für Bernd Schünemann zum 70. Geburtstag am 1. Nowember 2014, Berlin, Boston 2014, s.879 (s.875-889); VOLK/ENGLÄNDER, §30, kn. 4.

${ }^{20}$ GOETTGEN, s. 19.

${ }^{21}$ VOLK/ENGLAENDER, §30, kn. 5.

22 AMBOS, Kai/ZIEHN, Pamela: Strafprozessordnung, Kommentar, Herausgegeben von Radtke, Henning/Hohmann, Olaf, München 2011, §257c, kn. 3; BEULKE/SWOBODA, kn. 394a.

${ }^{23}$ AMBOS/ZIEHN, in: Radtke/Hohmann, §257c, kn. 3.

${ }^{24}$ ROTHE, Manuel/SZALAI, Stephan: "Der Deal im Strafprozess- Sunlicht is the best disinfectant?", in: NJOZ 2013, s.1803 (s.1801- 1807).

${ }^{25}$ VOLK/ENGLAENDER, §30, kn. 4.

${ }^{26}$ AMBOS/ZIEHN, in: Radtke/Hohmann, §257c, kn. 3.

${ }^{27}$ BEULKE/SWOBODA, kn. 394a.

28 ÖZTÜRK, Bahri/TEZCAN, Durmuş/ERDEM, Mustafa Ruhan/SIRMA GEZER, Özge/SAYGILAR KIRIT, Yasemin F./ALAN AKCAN, Esra/ÖZAYDIN, Özdem/ERDEN TÜTÜNCÜ, Efser/ALTINOK VILLLEMIN, Derya/TOK, Mehmet Can: Nazari ve Uygulamalı Ceza Muhakemesi Hukuku, 13. Bask1, Ankara Eylül 2019, s.151, 152.
} 
mecburiyeti ilkesi” (Legalitätsprinzip) denir ${ }^{29}$. Suçu takip etmekle görevli makamların, devletin cezalandırma talebi üzerinde tasarruf etme yetkileri bulunmamaktadır. Kamu davas1 sonuçlanıncaya kadar onu takip etmek zorunda olan savcının, mahkemeyle anlaşması kovuşturma mecburiyeti ilkesine aykırıdır ${ }^{30}$.

c. Hüküm anlaşması "maddi gerçeğin araştırılması" ilkesiyle çelişmektedir ${ }^{31}$. Maddi gerçeğin araştırılması ilkesi, soruşturma ve kovuşturma organlarının maddi gerçeği re'sen araştırmakla yükümlü olmalarını ifade eder. AlCMK $\$ 244 / 2$ gereğince $^{32}$, mahkeme gerçeği ortaya çıarma yükümlülüğünün gereği olarak, maddi olayı tespit etmek amacıyla re'sen araştırma yapar $^{33}$. Mahkeme uyuşmazlığa ilişkin her delili, her belirtiyi maddi gerçeği aydınlatıp aydınlatmadığı açısından değerlendirir ${ }^{34}$. Hüküm anlaşması ise, sanığın suçu ikrar etmesi üzerine daha hafif bir cezayla cezalandırılması esasına dayandığından, ikrardan sonra yeni delil ikamesinden, delillerin ortaya konulmasından ve tartışılmasından feragat edilir. Ancak bu durum "maddi gerçeğin araştırılması" ilkesi adına büyük bir risk taşımaktadır ${ }^{35}$. Zira mahkeme, sanığın ikrarı konusunda tereddüt etmesine veya bu ikrar konusunda tam olarak ikna olmamasına rağmen, uzun ve zahmetli yargılama süreçlerinden tasarruf etmek adına, hüküm anlaşmasına uygun hareket edebilir ve yeni delil ikamesinden vazgeçebilir ${ }^{36}$. Bunun anlamı; hüküm anlaşmasının, maddi gerçek ortaya konmadan, masumiyet karinesi yenilmeden veya maddi gerçeğe aykırı bir hükmün verilmesi riski taşıdığıdır ${ }^{37}$. Nitekim uygulamada deliller zayıf olmasına rağmen mahkemeler, sanığın yeterince açık ve güçlü olmayan ikrarına dayanarak, söz konusu ikrarın gerçeğe uygun olup olmadığını araştırmaksızın, hüküm kurabilmektedir ${ }^{38}$.

d. Hüküm anlaşması alenilik ve sözlülük ilkesine de aykırılık teşkil etmektedir. Sözlülük ilkesi, somut olaya ilişkin bütün delillerin duruşmaya getirilmesi ve tartışılmasını ifade eder. Duruşmada ortaya konarak tartışılmamış, tarafların bilgisine sunulmamış bir delilin hükme esas alınması mümkün değildir. Ceza muhakemesinde dosya üzerinden hüküm verilmez. Bütün delillerin sözlü duruşmada tartışılması gerekir ${ }^{39}$.

Ceza muhakemesinin aleniliği ilkesi ise, duruşmanın herkese açık olması anlamına gelir. Ceza muhakemesinde duruşmalar, hüküm ve diğer mahkeme kararlarının tefhimi alenidir ${ }^{40}$. Ancak Alman ceza hukuku uygulamasında hüküm anlaşmasının duruşma dışında, kapalı kapılar arkasında yapılması, duruşmada ise yalnızca bu müzakerelerde ulaşılan sonuçların açıklanması, ceza muhakemesinin sözlülük ve alenilik ilkeleri açısından bir tehdittir ${ }^{41}$. Sürecin tutanağa geçirilmesi konusundaki kanuna aykırı davranışlar, Anayasal ilkeleri ve ceza muhakemesinin temel ilkelerini tehdit etmektedir ${ }^{42}$. Uygulamada esasa ilişkin kararlar duruşma dışında alınıp, anlaşma yapıldıktan sonra, kamuya açık oturumda sanki anlaşma yapılıyormuş gibi davranılması, gösteriden öteye gitmemektedir ${ }^{43}$.

\footnotetext{
${ }^{29}$ ÖZTÜRK VE DİĞERLERİ, s.152; UĞUR, Hüsamettin: “Ceza Muhakemesinde Kovuşturma Mecburiyeti İlkesinden Maslahata Uygunluk İlkesine”, TBBD, S.73, Y. 2007, s.257.

${ }^{30} \mathrm{KREY} / \mathrm{HEINRICH}$, kn. 1508.

${ }^{31}$ ROTHE/SZALAI, NJOZ 2013, s.1803; KREY/HEINRICH, kn. 1509.

${ }^{32}$ Söz konusu düzenlemeye göre, mahkeme delillerin ortaya konulmasının kapsamını maddi gerçeğe ulaşmak amacıyla, karar için önemli tüm olgu ve delilleri kapsayacak şekilde kendiliğinden genişletir. İlkenin izlerine TCMK'da da rastlanmaktadır. TCMK m.207'de “delilin ortaya konulması isteminin, bunun ve ispat edilmek istenen olayın geç bildirilmiş olması nedeniyle reddedilemeyeceği”" ve TCMK m.225/2'de "mahkemenin, fiilin nitelendirilmesinde iddia ve savunmalarla bağlı olmadığ " yönündeki düzenlemeler, "maddi gerçeğin araştırılması" ilkesinin kovuşturma aşamasında mahkemeler açısından da geçerli olduğuna işaret etmektedir.

33 ÖZBEK, Veli Özer/DOĞAN, Koray/BACAKSIZ, Pınar: Ceza Muhakemesi Hukuku, 12. Baskı, Ankara Ağustos 2019, s.67-68. İlkenin sadece kovuşturma makamlarını değil soruşturma makamlarını da ilgilendiren yönleri bulunmaktadır. Bu açıdan soruşturma makamları maddi gerçeğin araştırılması ve adil yargılamanın yapılabilmesi için, şüphelinin lehine ve aleyhine olan bütün delilleri toplayarak muhafaza altına almakla yükümlüdür.

${ }^{34}$ YENISEY, Feridun/NUHOĞLU, Ayşe: Ceza Muhakemesi Hukuku, 7. Bask1, Ankara Ağustos 2019, s.79.

${ }^{35}$ BEULKE/SWOBODA, kn. 394a.

${ }^{36} \mathrm{KREY} / \mathrm{HEINRICH}$, kn. 1509.

37 MEYER-GOßNER, Lutz/SCHMITT, Bertram, Becksche Kurz Kommentare, Strafprozessordnung, 60. Aufl., München 2017, §257c, kn.3; DUTTGE, FS-Schünemann, s.884.

${ }^{38}$ ROENNAU, JuS 2018, s.115.

${ }^{39}$ YENISEY/NUHOĞLU, s.80.

40 YENISEY/NUHOĞLU, s.80.

${ }^{41}$ VOLK/ENGLAENDER, §30, kn. 4; BEULKE/SWOBODA, kn. 394a.

${ }^{42}$ DUTTGE, FS-Schünemann, s.876.

${ }^{43}$ DUTTGE, FS-Schünemann, s.879.
} 
Öte yandan, bazı hakimlerin hüküm anlaşmasına ilişkin müzakereleri ve sürecin ilerleyişini duruşma tutanağına geçirmeyi gereksiz bir formalite olarak değerlendirmeleri, duruşma tutanaklarının hüküm anlaşmalarının içeriğini tam olarak yansıttığı konusunda şüphe yaratmaktadır ${ }^{44}$. Anlaşma müzakerelerinin tutanăga geçirilmesi ve belgelenmesi konusundaki yasal düzenlemeyle, uzun yıllar boyunca mahkemelerde oluşmuş olan kötü alışkanlıkların bir anda değişmesini beklemek, naif bir yaklaşımdır ${ }^{45}$. Başarısızlıkla sonuçlanan anlaşma girişimleri, mahkemelerin AlCMK §257c'nin yasal sınırları içinde kalarak anlaşma yapma konusunda özenli davranmadıklarını göstermektedir ${ }^{46}$. Anlaşma sürecini tam olarak yansıtmayan, eksik duruşma tutanakları, üst mahkemeler açısından kanun yolu denetimi sırasında önemli bir problem yaratmaktadir ${ }^{47}$.

e. Kanunun hüküm anlaşması yapılmaya elverişli suçları açık bir şekilde saymak yerine, mahkemenin "uygun göreceği”" haller olarak genel bir ifade kullanması, Anayasal eşitlik ilkesine aykırıdır $^{48}$. $\mathrm{Bu}$ durumda aynı suçu işleyen bazı kişiler hakkında AlCMK §257c uygulanabilecekken bazıları hakkında uygulanamayacaktır. Bu açıdan düzenleme Alman Anayasası $§ 3$ 'de garanti altına alınmış olan eşitlik ilkesine aykırıdır ${ }^{49}$.

f. Hüküm anlaşması kovuşturmanın erken bir safhasında yapılırsa "doğrudan doğruyalık" ilkesini ihlal eder ${ }^{50}$. Doğrudan doğruyalık ilkesine göre hakimin vicdani kanaati, ancak duruşmada sunulan ve sözlü olarak tartışılan delillerin değerlendirilmesi neticesinde oluşmalı ve hakim bu delillere dayanarak bir hüküm kurmalıdır ${ }^{51}$. Hakim, duruşmada tartışılmayan, doğrudan temas etmediği bir delile dayanamaz. Hüküm anlaşmasında ise, basit bir usul uygulamaktadır ${ }^{52}$. Özellikle kovuşturma aşamasının başında, henüz deliller yeterince ortaya konulup tartışılmadan anlaşmayla muhakemenin hızlı bir şekilde sonlandırılması, doğrudan doğruyalık ilkesine aykırıdır ${ }^{53}$.

\section{HÜKÜM ANLAŞMASININ ŞARTLARI VE SONUÇLARI}

\section{A. Hüküm Anlaşmasının Kapsamı}

AlCMK §257c'nin uygulama alanıyla ilgili olarak herhangi bir suç kataloğu belirlenmemiş, yalnızca mahkemenin "uygun göreceği” hallerden söz edilmiştir. Kanunun gerekçesinde de işaret edilen hüküm anlaşması yapmaya "uygun haller"in neler olduğu konusunda bir açıklama yapılmamıştır. Bu nedenle hangi hallerin hüküm anlaşması yapmaya uygun, hangilerinin uygun olmadığı sorusuna net bir cevap vermek mümkün görünmemektedir ${ }^{54}$. Bu durumda hüküm anlaşması yapılmasına uygun bir halin mevcut olup olmadığı, somut olayın şartlarına göre mahkeme tarafindan belirlenecektir.

AlCMK §257c'nin gerekçesinde Federal Alman Mahkemesi'nin kararına atıf yapılarak yeterli inceleme yapılmadan, dosyayı hızlı bir şekilde sonlandırma saikiyle hareket edilmemesi gerektiği vurgulanmıştır ${ }^{55}$. Federal Alman Mahkemesi'nin atıf yapılan söz konusu kararına göre; mahkeme, görevinin gereklerine aykırı olarak iddianameyi ve dosyayı incelemeden, muhakemeyi hüküm anlaşması yoluyla çabucak sonlandırma yoluna gitmemelidir ${ }^{56}$. Mahkeme en azından, somut olayda hüküm anlaşması yapılmasına mani olacak fiili veya hukuki bir nedenin bulunup bulunmadığını araştırmalıdır. Mahkeme, muhakemenin hızlandırılmasının mümkün olduğu, böyle bir potansiyelin bulunduğu her davada, hüküm anlaşmas1 usulünü uygulayabilir ${ }^{57}$. Bu açıklamalardan hareketle, "hüküm anlaşmasının" muhakemenin hızlandırılması potansiyeli olan

\footnotetext{
${ }^{44}$ GOETTGEN, s.23.

${ }^{45}$ FISCHER, Thomas: "Ein Jahr Absprache-Regelung Praktische Erfahrungen und gesetzlicher Ergänzungsbedarf”, in: ZRP 2010, s.250.

${ }^{46}$ FISCHER, ZRP 2010, s.250.

${ }^{47}$ GOETTGEN, s.23-24.

${ }^{48}$ MURMANN, Uwe: “Reform ohne Wiederkehr?- Die gesetzliche Regelung der Absprachen im Strafverfahren”, in: ZIS 10/2009, s.535.

${ }^{49}$ MURMANN, ZIS 10/2009, s.535.

${ }^{50}$ BEULKE/SWOBODA, kn. 394a.

${ }^{51}$ ROENNAU, JuS 2018, s.115.

${ }^{52}$ KREY/HEINRICH, kn. 1510.

${ }^{53}$ BEULKE/SWOBODA, kn. 394a.

${ }^{54}$ MURMANN, ZIS 10/2009, s.534; ROXIN/ACHENBACH/JAEGER/HEINRICH, s.152.

${ }_{55}^{5 T}$ BT- Drucks.16/11736, s.11, Erişim: http://dip21.bundestag.de/dip21/btd/16/117/1611736. pdf, (Tarih: 08.12.2019).

${ }^{56}$ BGHSt 50, s.49.

${ }^{57}$ MURMANN, ZIS 10/2009, s.534.
} 
bütün ceza davalarında uygulanması mümkün, genel bir kurum olduğu söylenebilir ${ }^{58}$. Somut olayda, böyle bir potansiyelin olup olmadığını ve anlaşma yapıp yapmamayı davaya bakan mahkeme değerlendirecektir.

Öğretide, delillerin güçlü olduğu, maddi ve hukuki açıdan herhangi bir sorun içermeyen, bu nedenle zaten kısa sürede sonuçlandırılabilecek olan davaların, hüküm anlaşması yapılmasına elverişli olmadığına işaret edilmektedir ${ }^{59}$. Bu tür davalarda yapılan anlaşmadan beklenen fayda, gerçekten işlediği suçtan pişman olan veya soruşturma dosyasında eksikler bulunan, bu nedenle yargılamanın erken bir safhasında suçunu ikrar eden sanıkla yapılan anlaşmaya oranla çok daha azdır. Hatta, bu gibi durumlarda zaten mevcut delil durumu açık olduğundan ve sanığın ikrarının pratik bir önemi bulunmadığından, anlaşmadan beklenen somut hiçbir fayda olmayabilir ${ }^{60}$. Hüküm anlaşması sanığın cezasında indirim yapılması için getirilmiş, genel bir kurum olmadığından, ancak amaca uygunsa uygulanmalıdır. Hüküm anlaşmasının asıl amacı, ceza muhakemesini hızlandırmaktır. Bu amaçla yapılmayan anlaşmalar, kanunun amacına aykırıdır.

\section{B. Hüküm Anlaşmasının Konusu}

Hüküm anlaşması yalnızca muhakemenin işleyişi, hükmün içeriği ve sonuçları hakkında yapılabilir. Örneğin, cezanın türü, seçenek yaptırıma çevrilmesi, fer'i cezaya hükmedilip hükmedilmeyeceği, müsadere kararı verilip verilmeyeceği, cezanın ertelenip ertelenmeyeceği veya tutukluluk halinin devam edip etmeyeceği ${ }^{61}$ anlaşmanın konusu olabilir. Aynı şekilde mahkeme, muhakemenin taraflarıla belli bir muhakeme işleminin yapılma şekli (örneğin bir tanığın video konferans yöntemiyle dinlenmesi) veya o muhakeme işleminin yapılmasından veya belli bir delilin ikamesinden feragat edilmesi konusunda anlaşabilir ${ }^{62}$.

Bununla birlikte, sanığın kusuru veya güvenlik tedbirleri hüküm anlaşmasına konu olamaz. Bu nedenle, suçun nitelikli halini işlemiş olan sanığın, suçun temel şeklinden cezalandırılmasına ilişkin bir anlaşma yapılamaz ${ }^{63}$. Sanığın bir psikiyatri kliniğine yatırılması (AlCK §63), bağımlılıktan kurtulmak için bir tedavi merkezine yerleştirilmesi (AlCK §64) veya failin tehlikeliliğini esas alan başka bir güvenlik tedbiri konusunda yapılan hüküm anlaşması geçersizdir. Bunun gibi bir meslek veya sanatın icrasının yasaklanması veya sürücü belgesine el konması da hüküm anlaşmasına konu edilemez ${ }^{64}$.

Mahkeme, tarafların anlaşması halinde sanık hakkında hükmedeceği cezanın alt ve üst sınırlarını önceden bildirebilir. Ancak cezanın miktarı veya süresi konusunda kesin bir taahhütte bulunamaz $^{65}$. Örneğin, mahkeme altı ay hapis cezasına hükmedileceği gibi kesin bir cezay1 taahhüt edemez, ama altı ayla on iki ay arasında bir hapis cezasına hükmedeceğini açıklayabilir. Ayrıca mahkeme anlaşma gerçekleşirse hükmedeceğini bildirdiği cezanın alt ve üst sınırlarını belirlerken, sanığın kusurunun ağırlığını dikkate almak zorundadır. Mahkemenin belirlediği ceza aralığıyla sanığın kusuru arasında orantı olmalıdır. Hükmedilecek olan ceza, sanığın kusurunun ağırlığından az olamaz ${ }^{66}$. Bu nedenle, öğretide hüküm anlaşması için önerilen cezayla çekişmeli muhakeme neticesinde verilecek olan ceza arasında en fazla $\% 20$ veya $\% 30$ oranında bir fark olabileceği kabul edilmektedir. Buna göre, isnat olunan suça ilişkin olarak kanunda öngörülen cezada yapılması teklif edilen indirimin oranı $\% 20$ veya $\% 30$ 'u aşmamalıdır ${ }^{67}$.

Mahkemenin sadece cezanın üst sınırını belirleyip, alt sınıra ilişkin herhangi bir belirleme yapmamasının hüküm anlaşması için yeterli olup olmadığı ise tartışmalıdır. Ancak Federal Alman Mahkemesi yalnızca üst sınırın belirlenmesinin kanuna uygun olmayacağını, bu nedenle cezanın

\footnotetext{
${ }^{58}$ Aynı şekilde Amerikan hukukunda uygulanan "guilty plea", her suç açısından uygulanabilen, ceza yargılamasını kısaltan bir usuldür. Buna karşın bazı ülkeler ceza muhakemesini kısaltan kurumların uygulanması için, yasal cezaya ilişkin bir sınır belirlemişlerdir. Örneğin, İspanya'da on yıla, İsviçre'de ise beş yıla kadar hapis cezası gerektiren suçlarda, muhakemeyi hızlandıran usuller uygulanabilmektedir. Japonya'da ise ceza muhakemesini kısaltan uygulamalara, yalnızca cezanın ertelenmesi söz konusu olduğunda müsaade edilmektedir. Bilgi için bkz. DEITERS, Mark: “Abgekürzte Strafverfahren”, in: ZStW 2018 (130), s.499-500.

${ }^{59}$ MURMANN, ZIS 10/2009, s.535.

${ }^{60}$ MURMANN, ZIS 10/2009, s.535.

${ }^{61}$ KREY/HEINRICH, kn. 1515; MEYER- GOßNER/SCHMITT, StPO, §257c, kn. 15a.

62 VOLK/ENGLAENDER, §30, kn. 4a.

${ }^{63}$ BGH NJW 2011, s.1526.

${ }^{64}$ MEYER- GOßNER/SCHMITT, StPO, $\$ 257 \mathrm{c}, \mathrm{kn} .9$.

${ }^{65}$ BEULKE/SWOBODA, kn. 395a; VOLK/ENGLAENDER, §30, kn. 4a; KREY/HEINRICH, kn. 1516.

${ }^{66} \mathrm{KREY} / \mathrm{HEINRICH}, \mathrm{kn} .1515$.

${ }^{67}$ MEYER- GOßNER/SCHMITT, StPO, §257c, kn. 19.
} 
alt sınırının da anlaşma sırasında belirtilmesi gerektiğini kabul etmektedir. Mahkemeye göre; AlCMK §257c, 3. fikranın, 2. cümlesinde açıkça "cezanın alt ve üst sınırlarından”, ayrıca aynı paragrafın 4. fikrasının ilk cümlesinde de "önerilen ceza aralığından" bahsedilmektedir. Bu nedenle, anlaşma halinde hükmedilecek cezanın hem alt hem de üst sınırı önceden taraflara mutlaka bildirilmelidir ${ }^{68}$.

Muhakeme şartları ve kanun yollar1 ${ }^{69}$ konusunda yapılacak bir hüküm anlaşması da geçersizdir. Bu nedenle şikayetin geri alınmasına veya istinaf kanun yoluna gidilmeyeceğine ilişkin bir hüküm anlaşması yapılamaz. Aynı şekilde savcılığın başka bir delil araştırması veya yeni soruşturma yapmayacağı gibi bir hususta anlaşma yapılması da hukuka aykırıdır ${ }^{70}$.

Kanun yollarına başvurmaktan feragat edilmesinin hüküm anlaşması konusu yapılma yasağı, geçmişteki kötü uygulamalardan kaynaklanmaktadır. Alman ceza hukuku uygulamasında, önceleri kanun yoluna başvurmaktan feragat edilmesi, anlaşma şartı olarak getirilmekte ve böylece hükmün üst derece mahkemesi tarafından denetlenmesinin önüne geçilmekteydi. Ancak Federal Alman Mahkemesi anlaşmanın hukuka uygun olup olmadığının mutlaka denetlenmesi gerektiği, bu nedenle kanun yoluna başvurmaktan feragat şartıyla yapılan anlaşmanın geçersiz olduğu yönünde bir karar vermiştir ${ }^{71}$. Federal Alman Mahkemesi Büyük Dairesi verdiği kararda; kanun yolu başvurusundan vazgeçme konusunda yapılacak bir anlaşmanın geçersiz olduğunu, ayrıca sanığa hükmün tefhimi sırasında hükme karşı hangi kanun yollarına başvurabileceği, başvuru süresi ve başvuru usulü hakkında bilgi verilmesi gerektiğini vurgulamıştır ${ }^{72}$.

Kanun yoluna başvurma hakkından feragat, anlaşma şartı yapılamaz. Sanığa, hükme karşı başvurabileceği kanun yollarına ilişkin bilgi verilmemesi de hukuka aykırıdır. Bu kurallara aykırılık bozma nedenidir. AlCMK §257c'ye ilişkin kanun tasarısında, kanun yolundan feragat yasağının açıkça düzenlemesi önerilmiş̧ir. Ancak AlCMK §302/1, 2 cümlesinde yer alan "hüküm bir anlaşma neticesinde verilmişse, kanun yolu başvurusundan vazgeçilemez" açık bir düzenleme bulunduğu için, aynı hükmün AlCMK §257c'de tekrarlanması gereksiz bulunmuş ve öneri reddedilmiştir.

Cezanın infazıyla ilgili hususlarda veya muhakeme konusuyla bağlantısı olmayan konularda yapılan anlaşmalar da hukuka aykırıdır. Anlaşma şartı olarak, sanıktan muhakeme konusu olayla bağlantısı olmayan başka edimleri yerine getirmesi talep edilemez ${ }^{73}$. Örneğin, sanıktan mağdur haklarını koruyan veya mağdurlara yardım eden bir derneğe bağış yapması istenemez ${ }^{74}$. Veya mahkeme, hırsızlık ve suç eşyasını satın alma suçundan yargılanan sanığa, devlete olan vergi borcunu öderse, söz konusu suçlardan hakkında en fazla dört yıl hapis cezasına hükmedileceği şeklinde bir anlaşma öneremez ${ }^{75}$. Hüküm anlaşması yalnızca muhakeme konusu olayla bağlantılı hususlarda yapılabilir. Anlaşma konusu yapılan hususlar arasında mutlaka bir bağlantı olmalıdır ${ }^{76}$.

Sanık hakkında yürütülmekte olan bir başka soruşturma veya kovuşturma, hüküm anlaşmasının konusu olamaz. Bu itibarla savcının, sanığa suçunu ikrar ederse hakkında yürütülmekte olan başka bir davayla ilgili olarak, mahkemeden AlCMK §154/II gereğince "açılmış olan kamu davasının yürütülmesinin durdurulmasını" talep etmeyi teklif etmesi veya bu konuda bir anlaşma yapılması hukuka aykırıdır ${ }^{77}$.

\footnotetext{
${ }^{68}$ BGH NStZ 2011, s.648.

${ }^{69}$ AlCMK $\$ 302$ gereğince kanun yoluna başvurmaktan feragat edilebilir veya kanun yoluna başvurduktan sonra başvuru geri çekilebilir. AMBOS/ZIEHN, in: Radtke/Hohmann, §257c, kn. 29; MEYER- GOßNER/SCHMITT, StPO, $\S 257 \mathrm{c}, \mathrm{kn} .15 \mathrm{~b}$. TCMK m.266'da ise yapılmış olan kanun yolu başvurusundan vazgeçilebileceği düzenlenmiş olmasına rağmen, kanun yolu başvurusundan feragat edilmesi düzenlenmemiştir.

${ }^{70}$ BVerfG, NJW 2013, s.1064.

${ }^{71}$ BGHSt 50, s.40-64.

72 BGHSt 50, s.62.

${ }^{73}$ KREY/HEINRICH, kn. 1517-1518; BGHSt 49, s.89.

${ }^{74}$ MEYER-GOßNER/SCHMITT, StPO, \$257c, kn. 15a.

${ }^{75}$ ROXIN/ACHENBACH/JAEGER/HEINRICH, s.153, 154.

${ }^{76} \mathrm{KREY} / \mathrm{HEINRICH}, \mathrm{kn} .1517-1518$.

${ }^{77}$ KREY/HEINRICH, kn. 1519.
} 


\section{Suçu Kabul- İkrar}

AlCMK $\S 257 \mathrm{c} / 2$, 2. cümlede ikrarın hüküm anlaşmasının unsuru olması gerektiği belirtilmiştir. Bu düzenleme Alman ceza muhakemesi hukuku uygulaması açısından önemli bir yeniliktir. Ancak söz konusu ifade kesin bir emir değil gereklilik kipi içermektedir. Bu nedenle ikrar olmadan hüküm anlaşmasının yapılamayacağını söylemek doğru değildir ${ }^{78}$. Ancak kural olarak hüküm anlaşmasında sanığın suçu ikrar etmesi beklenir ve anlaşma ikrar üzerine gerçekleşir $^{79}$. Sanığın ikrarı, hüküm anlaşmasının başlangıç noktasıdır ${ }^{80}$.

Bununla birlikte kanunun gerekçesinde de ifade edildiği gibi, sanığın suçunu ikrar etmesi mahkemenin maddi gerçeği araştırma yükümlülüğünü ortadan kaldırmaz. İkrara rağmen mahkeme, maddi olayı açığa çıkarmak için gerekli araştırmaları yapmak zorundadır. Sanık kendisine teklif edilen cezayı kabul etmeye hazır olsa bile, mahkemenin maddi olayı araştırma yükümlülüğü devam eder ${ }^{81}$.

İkrar bizzat sanık tarafından ve sözlü olarak yapılmalıdır. Müdafinin, müvekkilinin suçunu ikrar ettiğini beyan etmesi veya yazılı olarak mahkemeye sunulan ikrar geçersizdir ${ }^{82}$.

Sanı̆̆ın "iddianamede anlatılan olaylar gerçeği yansıtmaktadır" şeklindeki, içerikten yoksun, tamamen şekli ikrarı, hüküm anlaşması için yeterli değildir. İkrar, samimi, nitelikli ve iddianamenin içeriğine ilişkin olmalıdır ${ }^{83}$. Sanık ikrarında, özellikle kovuşturma makamlarınca aydınlatılamamış olan noktaları açıklamalı, olayın ayrıntılarına ilişkin maddi gerçeğin aydınlatılmasına yarayan bilgiler vermelidir. İkrar tam olmalı, boşluk içermemelidir ${ }^{84}$. Ayrıca mahkeme, dosyadan hareketle ikrarın maddi olaya uygunluğunu araştırmalı, sanığın ikrarının gerçeğe uygunluğunu kontrol etmelidir ${ }^{85}$.

İkrar yalnızca gönüllü ve sanığın özgür iradesine dayanıyorsa hukuken geçerlidir. İkrar, dikkatli değerlendirilmesi gereken bir delildir ${ }^{86}$. Sanık başkasının işlemiş olduğu suçu, onu cezadan kurtarmak için üstlenmiş olabilir. Ya da ağır ceza tehdidiyle, suçu üstlenme ikilemi arasından kalan sanık, işlemediği bir suçu üstlenebilir. Ağır bir yaptırımla karşılaşma riskini bertaraf etmek isteyen sanık, hafif cezaya razı olarak işlemediği suçu itiraf edebilir. Bu nedenle ikrar anlaşma şartı olmamalı, sanığa anlaşmak istiyorsa suçunu itiraf etmesi gerektiği söylenerek baskı yapılmamalıdır. Sanık ikrara zorlanmamalıdır. İkrarın anlaşma şartı yapılması, masumiyet karinesi ve nemo tenatür ilkelerine aykırıdır. Ceza muhakemesinin maddi gerçeği ortaya çıkarma amacı, çabukluğa feda edilmemelidir. Sanı̆̆ın kendisini ikrar konusunda baskı altında hissetmesine yol açacak uygulamalardan kaçınılmalıdır. Nitekim AlCMK §257c'de bir anlaşmanın temel unsurunun ikrar olması gerektiğine işaret edilmiş, ancak ikrar anlaşmanın zorunlu unsuru haline getirilmemiştir.

Öte yandan ikrar, tek başına hükme esas alınmamalıdır. Sanığın suçluluğunu destekleyen başka deliller aranmalıdır. İkrar dışında, sanığın suçlu olduğunu gösteren başka bir delile ulaşılamazsa, şüpheden sanık yararlanır ilkesine uygun hareket edilmelidir.

\section{Usul}

Hüküm anlaşması yapmak, kural olarak mahkemenin inisiyatifindedir. Heyet halinde teşekkül eden mahkemelerde, hakimlerin en az üçte ikisi hüküm anlaşması usulünün uygulanması yönünde karar vermelidir. Bununla birlikte savcı veya müdafi de hüküm anlaşması usulünün

\footnotetext{
${ }^{78}$ ROTHE/SZALAI, NJOZ 2013, s.1806.

${ }^{79}$ MEYER-GOßNER/SCHMITT, StPO, §257c, kn. 16.

${ }^{80}$ AMBOS/ZIEHN, in: Radtke/Hohmann, $\$ 257 \mathrm{c}, \mathrm{kn} .25$.

${ }^{81}$ BVerfG, NJW 2013, s.1063; KREY/HEINRICH, kn. 1522.

${ }^{82}$ AMBOS/ZIEHN, in: Radtke/Hohmann, $\$ 257 \mathrm{c}, \mathrm{kn} .26$.

${ }^{83}$ ROXIN/ACHENBACH/JAEGER/HEINRICH, s.155-156.

${ }^{84}$ MEYER-GOßNER/SCHMITT, StPO, \$257c, kn. 17.

${ }^{85}$ VOLK/ENGLAENDER, $\$ 30$, kn. $4 \mathrm{a}$.

86 Ortaçağda ikrar delillerin şahı kabul edilmekte ve bu delilin elde edilmesi için gerekirse sanığa işkence yapılmaktaydı. Bkz. ÖZTÜRK VE DİĞERLERİ, s.85.
} 
uygulanmasını önerebilir. AlCMK $\S 160 b^{87}, \S 202 \mathrm{a}^{88}$ ve $\S 212^{89}$ gereğince savcı veya mahkeme muhakeme süjeleriyle bir araya gelip muhakemenin geldiği aşamayı değerlendirebilmektedir. $\mathrm{Bu}$ nedenle uygulamada anlaşma yapılıp yapılmayacağı, genellikle kovuşturma aşamasından önce, muhakemeye ilişkin hususlar değerlendirilirken gündeme gelmektedir. Ancak duruşma öncesinde taraflar arasında yapılan görüşmeler, henüz AlCMK \$257c anlamında bir hüküm anlaşması değildir ${ }^{90}$.

Mahkeme, muhakeme konusu olayın anlaşmaya uygun olduğu kanaatine ulaşırsa, muhakemenin diğer süjelerine anlaşma teklif eder. Sanık ve savcı, mahkemenin anlaşma önerisini değerlendirir ve kararını bildirir ${ }^{91}$. Mahkeme anlaşma teklifi konusunda yalnızca savcı ve sanığın veya onu temsil eden müdafinin değil, diğer muhakeme süjelerinin, özellikle davaya katılan kişilerin görüşlerini de alır. Ancak katılanın onayı, anlaşmanın geçerlilik şartlarından biri değildir. Katılanın itirazı, anlaşmasının yapılmasına engel olmaz. Anlaşmanın konusu hükmün içeriği ve sonuçları olduğundan, katılanın bu hususlar üzerinde zaten bir tasarruf yetkisi bulunmamaktadır. Ancak katılan, anlaşmaya karşı çıkarak, savcının ve mahkemenin görüşlerini etkileyebilir ${ }^{22}$. Aynı şekilde müdafinin anlaşmayı kabul edip etmemesi de önemsizdir. Sanık anlaşmak istiyorsa, ayrıca müdafinin onayının alınmasına gerek yoktur ${ }^{93}$.

$\mathrm{Bu}$ açıdan, anlaşma teklifini kabul edecek süjeler sanık ve savcıdır. Sanığın yokluğunda müdafi, savcı ve mahkeme arasında yapılan anlaşma geçersizdir ${ }^{94}$.

Mahkemenin teklifi, diğer muhakeme süjeleri tarafından açık bir şekilde kabul edilirse, anlaşma gerçekleşir ${ }^{95}$. Teklifin zımnen kabulü yeterli olmaz, açık beyan şarttır. Hem savcı hem de sanık anlaşmayı kabul ettiğini açıkça beyan etmelidir ${ }^{96}$.

Hüküm anlaşması duruşma dışında kapalı kapılar ardında değil, duruşmada herkesin gözü önünde, aleni bir şekilde yapılmalıdır ${ }^{97}$. Gizlice, duruşma dışında yapılan anlaşma, yani hüküm pazarlığı (deal) yasa dışıdır ${ }^{98}$. Ancak anlaşma hazırlığı duruşma dışında yapılan müzakerelerle yürütülebilir ${ }^{99}$. Bununla birlikte hüküm anlaşmasına ilişkin müzakereler ve müzakere sonucu, mutlak surette duruşma tutanağına geçirilmelidir. Hem duruşma sırasında hem de duruşma aralarında yapılan görüşmeler belgelenmelidir. Bütün sürecin tutanak altına alınması, muhakemenin aleniyeti açısından vazgeçilemez niteliktedir. Alman kanun koyucu AlCMK §257c ile hüküm anlaşmasının tam bir şeffaflık içinde yapılmasını, sürece ilişkin bütün ayrıntıların duruşma tutanağına geçirilmesini öngörerek, aleniyetin sağlanmasını amaçlamıştır. Kanunun hiçbir şekilde dolanılmaması, bütün sürecin en açık şekliyle tutanağa bağlanması yasal zorunluluktur. Yalnızca aleniyet ilkesini tam olarak karşılayan, bütün sürecin açık ve ayrıntılı olarak tutanağa bağlandığı hüküm anlaşmaları hukuken geçerlidir ${ }^{100}$.

Tutanağa bağlama kuralı, müzakerelerin hem olumlu hem de olumsuz sonuçlandığı haller için geçerli mutlak bir kuraldır. Müzakereler olumsuz sonuçlansa ve anlaşma sağlanamasa bile, süreç ayrıntılı bir şekilde belgelenmelidir. Müzakerelere ilişkin yeterli bilgi içermeyen duruşma tutanağı eksiktir ve bu açıdan ispat gücü zayıftır. Müzakerelerin tutanağa bağlanmasından kısmen veya tamamen feragat edilmesi kanunun ihlalidir. Aleniyet ilkesini ihlal eden ve ayrıntıları tutanağa geçirilmemiş, iyi belgelenmemiş bir anlaşmayı esas alan hükme karşı, AlCMK $§ 337$

\footnotetext{
${ }^{87}$ Muhakemenin geldiği aşamanın değerlendirilmesi başlığını taşıyan söz konusu düzenlemeye göre: "Savcllık, uygun gördüğ̈̈ hallerde, muhakemeye yardımcı olmak amacıyla, muhakemenin bulunduğu aşamayı muhakeme süjeleri ile görüşebilir. Yapılan değerlendirmenin önemli olan hususları tutanağa geçirilir”."

${ }^{88}$ Kovuşturma öncesi değerlendirme başlığını taşıyan söz konusu düzenlemeye göre; "Mahkeme kovuşturma evresine geçmeyi düşünüyorsa, muhakeme açısından yararlı olacaksa, muhakemenin içinde bulunduğu durumu, süjelerle birlikte değerlendirebilir. Yapılan bu değerlendirmenin ana hatları dosyaya ișlenir".

89 Kovuşturma açılmasından sonraki değerlendirme başlığını taşıyan söz konusu düzenlemeye göre; " $\$ 202 a$ kovuşturma evresine geçildikten sonra da uygulanır".

${ }^{90}$ MEYER-GOßNER/SCHMITT, StPO, \$257c, kn. 23.

${ }^{91}$ MEYER-GOßNER/SCHMITT, StPO, §257c, kn. 23.

92 MEYER-GOßNER/SCHMITT, StPO, \$257c, kn. 24.

${ }^{93}$ VOLK/ENGLAENDER, §30, kn. 4a.

${ }^{94}$ BGHSt 43, s.206 (s.195-212)

${ }^{95}$ MEYER-GOßNER/SCHMITT, StPO, §257c, kn. 25.

${ }^{96} \mathrm{VOLK} / \mathrm{ENGLAENDER,} 330$, kn. $4 \mathrm{a}$.

${ }^{97}$ ROTHE/SZALAI, NJOZ 2013, s.1804.

${ }^{98}$ MEYER-GOßNER/SCHMITT, StPO, §257c, kn. 4a.

${ }^{99} \mathrm{KREY} / \mathrm{HEINRICH}, \mathrm{kn} .1529$.

${ }^{100}$ GOETTGEN, s.23.
} 
gereğince "hükmün kanun ihlal edilerek verildiği" gerekçesiyle temyiz kanun yoluna başvurulabilir. Hükmün bir kanun ihlal edilerek verilmesi, temyiz nedenidir ${ }^{101}$.

Sanı̆̆ı, yüksek ceza tehdidiyle korkutmak hukuka aykırıdır. Örneğin sanığa; “anlaşırsa, hakkında en fazla iki yıl hapis cezasına hükmedileceği; anlaşmazsa muhakeme sonunda en az altı yıl hapis cezasına çarptırılacağı" söylenmemeli, sanık ağır ceza tehdidiyle korkutulmamalıdır ${ }^{102}$.

AlCMK §267'ye göre, gerekçesiz hüküm olmaz. Mahkeme tarafindan verilen her hükmün mutlaka bir gerekçesi olmak zorundadır. AlCMK §267'de gösterilen unsurları içermeyen ve gerekçesiz olarak yazılan kararlar bozmayı gerektirir ${ }^{103}$. Mahkemenin, muhakemenin süjeleriyle yaptığı bir anlaşma sonucunda verdiği hüküm de gerekçeli olmak zorundadır. Hükümde, mahkemeyle muhakeme süjeleri arasında bir anlaşma yapıldığı ve hükmün bu anlaşmaya dayandığ 1 açıkça belirtilmelidir ${ }^{104}$.

Mahkeme, kanun yoluna başvurma hakkı olan kişilere, özellikle sanığa AlCMK §35a gereğince söz konusu hükme karşı kanun yoluna başvurma hakkını kullanmakta serbest olduğunu bildirir. Sanık hükme karşı başvurabileceği kanun yolu, kanun yoluna başvuru süresi ve başvuru usulü konusunda ayrıntılı ve açık bir şekilde bilgilendirilir. Mahkeme, sanığın haklarını anladığından emin olmalıdır ${ }^{105}$. Kanun yolu başvurusundan vazgeçildiğine ilişkin bir anlaşma ise, yukarıda da işaret edildiği gibi, AlCMK $\S 302 / 1$, 2. cümle gereğince geçersizdir.

\section{E. Hüküm Anlaşmasının Bağlayıcılığı}

Hüküm anlaşması esas itibariyle mahkemeyi bağlar. Savcı ve sanığın, mahkemenin anlaşma teklifini kabul etmesinden sonra, mahkeme kural olarak yapılan anlaşmayla bağlıdır. Mahkeme, artık anlaşmaya uymak ve bir hüküm kurmak zorundadır. Mahkemenin anlaşmayla bağlı olması sanığın mahkemeye ve sürece güven duyması açısından önemlidir ${ }^{106}$.

Ancak anlaşmanın mahkeme açısından bağlayıcılığı mutlak değildir. Bazı durumlarda anlaşmanın bağlayıcılığı mahkeme açısından son bulur. Çünkü anlaşmanın mahkeme açısından mutlak şekilde bağlayıcı kabul edilmesi, maddi gerçeğin araştırılması ilkesini tehlikeye düşürür. Anlaşmanın mahkeme açısından kural olarak bağlayıcı olması, sanığın mahkemeye ve sürece güvenmesini temin etmektedir. İstisnai durumlarda anlaşmanın bağlayıcılığının sona ermesi ise, ceza muhakemesinin maddi gerçeğin ortaya çıkartılması amacına hizmet eden bir yaklaşımdır ${ }^{107}$. $\mathrm{Bu}$ nedenle Alman kanun koyucunun kural-istisna dengesine uygun bir şekilde, kanunda gösterilen belli şartlar altında, anlaşmanın bağlayıcılığının sona ereceğini açıkça düzenlemesi son derece isabetlidir (AlCMK $\$ 257 \mathrm{c} / 4)$.

AlCMK §257c/4'e göre mahkeme, hukuki veya maddi açıdan önemli olan bazı hususları gözden kaçırdığını fark ederse, hüküm anlaşmasından vazgeçebilir. Aynı şekilde, anlaşma yapıldığı anda bilinmeyen ancak hukuki veya maddi açıdan hükme etki eden bazı hususlar, anlaşma yapıldıktan sonra ortaya çıkar ve mahkeme bu nedenle önerdiği ceza aralığının fiile ve failin kusuruna uygun olmadığı kanaatine ulaşırsa, hüküm anlaşmasından cayabilir. Örneğin, mahkeme suçun temel şeklinin değil nitelikli halinin işlendiği kanaatine sonradan ulaşırsa, anlaşmayla bağlı olmadığını açıklayabilir. Sanığın muhakemenin devamındaki davranışlarının, mahkemenin sanıktan beklediği davranışlarla örtüşmemesi durumunda da mahkeme anlaşmadan dönebilir ${ }^{108}$.

Anlaşmanın bazı durumlarda mahkemeyi bağlamayacak olması, öğretide problemli bulunarak, eleştirilmektedir. Haklılık payı olan bu eleştiriye göre; kanunun yalnızca anlaşma yapıldıktan sonra ortaya çıkan yeni durumları değil, anlaşma sırasında mevcut olan ancak mahkemenin dikkatinden kaçan hususları da cayma nedeni sayması, mahkemenin hatasından sanığın sorumlu tutulması anlamına gelmektedir ${ }^{109}$. Mahkemenin anlaşma yapıldığı sırada

${ }^{101}$ GOETTGEN, s.24; VOLK/ENGLAENDER, §30, kn. 4a; BVerfG, NJW 2013, s.1063.

102 VOLK/ENGLAENDER, §30, kn. 4a.

${ }^{103}$ MEYER-GOßNER/SCHMITT, StPO, §257c, kn. 21.

${ }^{104}$ VOLK/ENGLAENDER, $\$ 30, \mathrm{kn} .4 \mathrm{a}$.

105 VOLK/ENGLAENDER, §30, kn. 4a.

106 TSUJIMOTO, Norio: "Eine inhaltliche Analyse der Verständigung im deutschen Strafprozess aus der Perspektive eines Außenstehenden", in: ZIS 12/2012, s.615 (s.612-622).

107 TSUJIMOTO, ZIS 12/2012, s.615.

${ }^{108}$ VOLK/ENGLAENDER, §30, kn. 5.

${ }^{109}$ MURMANN, ZIS 10/2009, s.538. 
mevcut olan hususları gözden kaçırmasının sonuçlarına, sanığın katlanmasını beklemek haksızlıktır. Ayrıca bu düzenleme, savunmanın mahkeme tarafindan yönlendirilmesi riski taşımaktadır. Zira, mahkemenin sanıktan beklediği davranış tarzı, savunmayı sınırlandırabilir ve sanık üzerinde baskı yaratabilir. Mahkemenin sanıktan beklediği davranışlar, sanığın anlaşma dışında kalan, savunmaya ilişkin diğer davranışlarını etkileyebilir ${ }^{110}$.

Anlaşmanın geçersiz hale gelmesi için, mahkeme anlaşmayla bağlı olmadığına dair bir karar almalıdır. Bu karar aslında, mahkemenin anlaşma yapmak için teklif ettiği ceza aralığının, artık geçerli olmadığını açıklamasından ibarettir ${ }^{111}$. Cayma kararıyla mahkeme anlaşmayı tek taraflı olarak fesheder ve anlaşmanın geçersiz olduğunu açıklar. Karar gecikmeksizin muhakeme süjelerine bildirilmelidir. Mahkeme anlaşmayla bağlı olmadığını açıkladığında, sanığın ikrarı da geçersiz hale gelir. Söz konusu ikrar artık hükme esas alınamaz (AlCMK §257c/2, 3. cümle). Delil değerlendirme yasakları kapsamında kalan ikrar, sanık aleyhinde kullanılamasa da lehinde kullanılabilir. Mahkeme anlaşmadan caydıktan sonra verdiği yeni hükümde, sanığın geçersiz hale gelen önceki ikrarını cezada indirim yapmak üzere göz önünde bulundurabilir ${ }^{112}$.

Öğretide, ikrarın geçersiz hale gelmesinden sonra, ikrar neticesinde elde edilen diğer delillerin durumu da değerlendirilmiştir ${ }^{113}$. Alman ceza muhakemesi hukukunda ${ }^{114}$ delil yasakları konusunda, ağırlıklı olarak nispi değerlendirme yasağı görüşü benimsenmektedir. Nispi değerlendirme yasağına göre; bir hak ihlal edilerek, hukuka aykırı olarak elde edilen bir delil, otomatik olarak yasal delil olarak sınıflandırılmaz. Böyle bir delilin bazı durumlarda kullanılması mümkündür. Somut olayda delilin elde edilmesi sırasında ihlal edilen hak ile delilin hukuka aykırı olmasından dolayı kabul edilmemesi halinde ihlal edilecek olan hak arasında bir değerlendirme yapılır. Bu değerlendirmede; şüpheli veya sanığın, delilin elde edilmesi amacıyla ihlal edilen hakkı ağır basıyorsa, delil geçersizdir. Buna karşın, suçların cezalandırılmasına ilişkin devletin menfaati ağır basıyorsa, delil hukuka aykırı olsa bile, değerlendirilir. Delil elde edilirken, sanığın hakları "önemli ölçüde ihlal edilmişse", ilgili delil değerlendirme dışı bırakılır. Delil şüpheli veya sanığın bir temel hakkı ihlal edilerek elde edilmişse, o delil hiçbir şekilde kullanılamaz. Ancak "ihlal ikincil nitelikteyse veya sanığın hakları açısından hiçbir önem taşımıyorsa", hukuka aykırı yollarla elde edilen delil kullanılabilir. Aynı şekilde hukuka aykırı bir delilden hareketle elde edilen ikincil delillerin değerlendirilip değerlendirilmeyeceği yani hükme esas alınıp alınmayacağı konusunda da nispi değerlendirme yapılması gerektiği görüşü, Alman ceza hukukunda hakim görüştür ${ }^{115}$.

İkrar geçerliliğini kaybettikten sonra, ona bağlı olarak elde edilen diğer delillerin de delil yasakları kapsamında olduğu ve değerlendirilemeyeceği görüşü, Alman ceza muhakemesi öğretisinde azınlıkta kalmaktadır ${ }^{116}$. Öğretide, ikrar geçersiz hale gelse bile, ona bağlı olarak elde edilen ikincil delillerin değerlendirme yasağı kapsamında olmadığı görüşü ağırlıklı olarak savunulmaktadır. AlCMK §257c'nin lafzının ve hüküm anlaşması kurumunun tarihi gelişiminin bu görüşü desteklediği iddia edilmektedir ${ }^{117}$. Bu durumda anlaşma geçersiz hale gelse ve ikrar değerlendirmesi yasak deliller arasına girse bile, ikrara bağlı olarak elde edilen diğer deliller değerlendirilebilir ve hükme esas alınabilir ${ }^{118}$.

Mahkeme sanığa anlaşma teklif ederken, anlaşmanın kural olarak mahkemeyi bağladığını, ancak kanunda sayılan bazı istisnai nedenlerin ortaya çıkması durumunda, anlaşmadan dönebileceğini ve bu durumda anlaşmadan bağımsız bir hüküm vereceğini açıklamalıdır. Sanık

\footnotetext{
${ }^{110}$ VOLK/ENGLAENDER, $\S 30$, kn. 5.

${ }^{111}$ KREY/HEINRICH, kn. 1528.

112 BGHSt 42, s.194 (191-194); AMBOS/ZIEHN, in: Radtke/Hohmann, §257c, kn. 37.

${ }^{113}$ GOETTGEN, s.42-44.

${ }^{114}$ Bkz. KREY/HEINRICH, kn. 1591-1595; BGHSt 38, s.219-220 (s.214-231).

115 Bkz. KREY/HEINRICH, kn. 1632. Bununla birlikte öğretide hukuka aykırı delillerin uzak etkisini kabul ederek, zehirli ağacın meyvesinin de zehirli olacağı görüşünü savunan yazarlar da vardır. bkz. KUHNE, Hans-Heiner, Strafprozessrecht- Eine systematische Darstellung des deutschen und europäischen Strafverfahrensrechts, 9. Aufl., Heidelberg 2015, kn. 912 vd.

116 KUHNE, kn. 912 vd.

117 GOETTGEN, s.43- 44.

${ }^{118}$ Beulke/Swoboda'ya göre; hüküm anlaşması mahkemenin hukuki veya fiili bir durumu gözden kaçırması nedeniyle geçersiz hale gelirse, sanığın ikrarına bağlı olarak elde edilen ikincil deliller de değerlendirilemez ve hükme esas alınamaz. Yazarlara göre, anlaşmanın mahkemenin hatası dışında başka bir nedenle geçersiz hale gelmesi durumunda ise, ikrarın uzak etkisi önemsizdir. İkrar geçersiz olsa bile, ona bağlı ikincil deliller değerlendirilebilir. Bkz. BEULKE/SWOBODA, kn. 396c.
} 
mahkemenin anlaşmadan caymasına yol açan istisnai nedenler ve caymanın sonuçları konusunda, ayrıntılı olarak aydınlatılmalıdır ${ }^{119}$. Aydınlatma mutlaka sürecin başında, anlaşma teklifi yapıldığı sırada, sanık henüz teklife ilişkin kararını açıklamadan ve her halükarda sanık suçunu ikrar etmeden önce yapılmalıdır ${ }^{120}$. İkrardan sonra yapılacak aydınlatma geçersizdir. Mahkemenin anlaşmadan caymasının nedenleri ve caymanın sonuçları sanığa açıklanmazsa, AlCMK §257c/5'e aykırı hareket edilmiş olur. AlCMK $\$ 337 / 2$ 'ye göre, bir hukuk kuralının uygulanmaması veya yanlış uygulanması temyiz nedenidir. Aydınlatma yükümlülüğünün ihlali, hükmün bozulmasını gerektirir.

Alt derece mahkemesinin yaptığı anlaşma, istinaf veya temyiz incelemesi yapan üst derece mahkemelerini bağlamaz ${ }^{121}$. Örneğin, ilk derece mahkemesi, muhakeme süjeleriyle yaptığ anlaşmaya dayanarak sanık hakkında 15 ay hapis cezasına hükmeder ve ardından da hükmettiği cezayı erteler. Ancak, savcı verilen cezanın az olduğu gerekçesiyle istinaf kanun yoluna başvurur. $\mathrm{Bu}$ durumda ilk derece mahkemesinin anlaşma sırasında belirlediği 12-18 aylık ceza aralığı, üst derece mahkemesi açısından bağlayıcı değildir. Ayrıca sanığın anlaşmak için yaptığı ikrar, istinaf mahkemesinde delil olarak değerlendirilemez ${ }^{122}$. Anlaşmanın üst derece mahkemeleri açısından bağlayıcı olmaması, kanun yolu denetiminin gereğidir. Zira kanun yolu denetiminde üst derece mahkemesi, alt derece mahkemesinin vermiş olduğu kararı istinafta maddi ve hukuki, temyizde ise hukuki açıdan denetler.

Mahkemenin anlaşma teklifini kabul eden savcılığın beyanı, kendisi açısından bağlayıcıdır. Savcılık anlaşmayı kabul ettikten sonra, hukuki veya maddi açıdan önemli hususları gözden kaçırdığını veya mahkemenin önerdiği ceza aralığının fiille ve failin kusurunun ağırlığıyla orantılı olmadığını fark etse bile, anlaşmadan dönemez ${ }^{123}$. Mahkemenin aksine, savcıllğa anlaşmadan cayma hakkı tanınmamıştır. Bununla birlikte, mahkemenin anlaşmadan cayma kararı, savcıyı da anlaşmayla bağlı olmaktan kurtarır ${ }^{124}$.

Sanık açısından ise, hüküm anlaşmasının bir bağlayıcılığı yoktur. Sanık anlaşmadan her zaman cayabilir. Sanık, daha önce yapmış olduğu ikrarı geri çekmekte serbesttir. Sanığın savunma hakkı kapsamında ikrarını her an geri çekip, suçsuz olduğunu iddia etme hakkı vardır. Hüküm anlaşması gönüllü olmalı ve sanığın özgür iradesine dayanmalıdır. Sanık anlaşma yapma konusundaki beyanına sadık kalmaya zorlanamaz. Sanığın anlaşmayı önce kabul edip, suçunu ikrar ettikten sonra, bundan vazgeçmesi, AlCMK $\$ 257 \mathrm{c} / 4$, 2. cümlede belirtilen, sanığın "muhakeme sırasındaki davranışlarıyla, sonraki davranışlarının mahkemenin öngörüsüne uymaması" durumuna örnek gösterilebilir. Bu durumda anlaşmanın mahkeme açısından bağlayıcılığı sona erer ve mahkeme artık sanık hakkında anlaşmadan bağımsız yeni bir karar verebilir ${ }^{125}$.

\section{ALCMK \$257C'DE DÜZENLENEN HÜKÜM ANLAŞMASI VE TCMK M.250'DE DÜZENLENEN SERİ MUHAKEME USULÜ BENZER KURUMLAR MIDIR?}

Türk Ceza Muhakemesi Kanunu'nun 250. maddesi 7188 sayılı Kanun'un 23. maddesiyle yeniden düzenlenmiştir. Söz konusu düzenlemeyle, "seri muhakeme usulü” (TCMK m.250) getirilmiştir. Madde gerekçesinde, benzer bir kurumun AlCMK $§ 257 \mathrm{c}$ 'de de mevcut olduğundan söz edilmiştir. $\mathrm{Bu}$ nedenle bu iki kurum arasında bir benzerlik olup olmadığına da kısaca değinmek gerekmektedir.

TCMK m.250'ye göre ${ }^{126}$, kanunda sayılan katalog suçlardan birinin işlendiğini öğrenen Cumhuriyet savcısı soruşturmanın son aşamasında, kamu davasının açılmasının ertelenmesi

\footnotetext{
${ }^{119}$ ROTHE/SZALAI, NJOZ 2013, s.1804.

${ }^{120}$ GOETTGEN, s. 18 .

${ }^{121}$ VOLK/ENGLAENDER, $\$ 30, \mathrm{kn} .7$.

122 VOLK/ENGLAENDER, $\$ 30, \mathrm{kn} .7$.

${ }^{123}$ MEYER-GOßNER/SCHMITT, StPO, §257c, kn. 25.

${ }^{124}$ KREY/HEINRICH, kn. 1529.

${ }^{125}$ KREY/HEINRICH, kn. 1526.

${ }^{126}$ Madde 250- (1) Soruşturma evresi sonunda aşağıdaki suçlarla ilgili olarak kamu davasının açılmasının ertelenmesine karar verilmediği takdirde seri muhakeme usulü uygulanır:
}

a) Türk Ceza Kanununda yer alan;

1. Hakkı olmayan yere tecavüz (madde 154, ikinci ve üçüncü fikra),

2. Genel güvenliğin kasten tehlikeye sokulması (madde 170),

3. Trafik güvenliğini tehlikeye sokma (madde 179, ikinci ve üçüncü fikra),

4. Gürültüye neden olma (madde 183), 
kararı vermesine engel bir durum varsa, kamu davasının açılmasının ertelenmesi kararı verilemiyorsa şüpheliye seri muhakeme usulü uygulamayı teklif eder. Şüpheli müdafi huzurunda Cumhuriyet savcısının teklifini kabul ederse, Cumhuriyet savcısı TCK m.61/1 gereğince şüpheli hakkında uygulanacak temel cezayı belirler ve bu ceza üzerinden yarı oranında indirim yapar (TCMK m.250/4). Cumhuriyet savcısı şartların oluştuğu kanaatine ulaşırsa, belirlediği cezayı TCK m.50 gereğince seçenek yaptırıma çevirebilir, TCK m.51 gereğince cezanın ertelenmesine (TCMK m.250/5) veya TCMK m.231 gereğince hükmün açıklanmasının geri bırakılmasına (TCMK m.250/6) karar verebilir. Ardından bir talepname düzenleyerek görevli mahkemeden seri muhakeme usulünün uygulanmasını ve talepnamede belirtilen doğrultuda hüküm kurmasını ister ${ }^{127}$. Şüpheli seri muhakeme usulünün uygulanmasını kabul ederse aynı gün mahkemeye yönlendirilir ${ }^{128}$. Mahkeme talepnamenin verildiği gün incelemesini derhal yapar ve şüpheliyi seri muhakeme usulünün uygulanmasına ilişkin olarak dinledikten sonra TCMK m.250/3'de sayılan şartların gerçekleşip gerçekleşmediğini kontrol eder ${ }^{129}$. Yani, seri muhakeme usulünün

5. Parada sahtecilik (madde 197, ikinci ve üçüncü fikra),

6. Mühür bozma (madde 203),

7. Resmi belgenin düzenlenmesinde yalan beyan (madde 206),

8. Kumar oynanması için yer ve imkan sağlama (madde 228 , birinci fikra),

9. Başkasına ait kimlik veya kimlik bilgilerinin kullanılması (madde 268),

suçları.

b) 10/7/1953 tarihli ve 6136 sayılı Ateşli Silahlar ve Bıçaklar ile Diğer Aletler Hakkında Kanunun 13 üncü maddesinin birinci, üçüncü ve beşinci fikraları ile 15 inci maddesinin birinci, ikinci ve üçüncü fikralarında belirtilen suçlar.

c) 31/8/1956 tarihli ve 6831 sayılı Orman Kanununun 93 üncü maddesinin birinci fikrasında belirtilen suç.

d) 13/12/1968 tarihli ve 1072 sayılı Rulet, Tilt, Langırt ve Benzeri Oyun Alet ve Makinaları Hakkında Kanunun 2 nci maddesinde belirtilen suç.

e) 24/4/1969 tarihli ve 1163 sayılı Kooperatifler Kanununun ek 2 nci maddesinin birinci fikrasının (1) numaralı bendinde belirtilen suç.

(2) Cumhuriyet savcısı veya kolluk görevlileri, şüpheliyi, seri muhakeme usulü hakkında bilgilendirir.

(3) Cumhuriyet savcısı tarafından seri muhakeme usulünün uygulanması şüpheliye teklif edilir ve şüphelinin müdafii huzurunda teklifi kabul etmesi hâlinde bu usul uygulanır.

(4) Cumhuriyet savcısı, Türk Ceza Kanununun 61 inci maddesinin birinci fikrasında belirtilen hususları göz önünde bulundurarak, suçun kanuni tanımında öngörülen cezanın alt ve üst sınırı arasında tespit edeceği temel cezadan yarı oranında indirim uygulamak suretiyle yaptırımı belirler.

(5) Dördüncü fikra uyarınca sonuç olarak belirlenen hapis cezası Cumhuriyet savcısı tarafindan, koşulları bulunması hâlinde Türk Ceza Kanununun 50 nci maddesine göre seçenek yaptırımlara çevrilebilir veya 51 inci maddesine göre ertelenebilir.

(6) $\mathrm{Bu}$ maddeye göre belirlenen yaptırımlar hakkında, Cumhuriyet savcısı tarafından, koşulları bulunması hâlinde 231 inci madde kıyasen uygulanabilir.

(7) Bu madde kapsamında yaptırım uygulanması, güvenlik tedbirlerine ilişkin hükümlerin uygulanmasına engel teşkil etmez.

${ }^{127}$ Madde 250- (8) Cumhuriyet savcısı, şüpheli hakkında seri muhakeme usulünün uygulanmasını yazılı olarak görevli mahkemeden talep eder. Talep yazısında;

a) Şüphelinin kimliği ve müdafii,

b) Mağdur veya suçtan zarar görenlerin kimliği ile varsa vekili veya kanuni temsilcisi,

c) İsnat olunan suç ve ilgili kanun maddeleri,

d) İsnat olunan suçun işlendiği yer, tarih ve zaman dilimi,

e) Şüphelinin tutuklu olup olmadığı; tutuklanmış ise, gözaltına alma ve tutuklama tarihleri ile bunların süreleri,

f) İsnat olunan suçu oluşturan olayların özeti,

g) Üçüncü fikrada belirtilen şartların gerçekleştiği,

h) Belirlenen yaptırım ile beşinci ve altıncı fikra uygulanmış ise bunlara ilişkin hususlar ve güvenlik tedbirleri, gösterilir.

${ }^{128}$ Ceza Muhakemesinde Seri Muhakeme Yönetmeliği m.10/9, 31 Aralık 2019 Tarih ve 30995 (4. Mükerrer) sayılı Resmi Gazete.

${ }^{129}$ Madde 250- (9) Mahkeme, şüpheliyi müdafii huzurunda dinledikten sonra üçüncü fikradaki şartların gerçekleştiği ve eylemin seri muhakeme usulü kapsamında olduğu kanaatine varırsa talepte belirlenen yaptırım doğrultusunda hüküm kurar; aksi takdirde talebi reddeder ve soruşturmanın genel hükümlere göre sonuçlandırılması amacıyla dosyayı Cumhuriyet başsavcılığına gönderir. Mazeretsiz olarak mahkemeye gelmeyen şüpheli, bu usulden vazgeçmiş sayılır.

(10) Seri muhakeme usulünün herhangi bir sebeple tamamlanamaması veya soruşturmanın genel hükümlere göre sonuçlandırılması amacıyla Cumhuriyet başsavcılığına gönderilmesi hâllerinde, şüphelinin seri muhakeme usulünü kabul ettiğine ilişkin beyanları ile bu usulün uygulanmasına dair diğer belgeler, takip eden soruşturma ve kovuşturma işlemlerinde delil olarak kullanılamaz.

(11) Suçun iştirak hâlinde işlenmesi durumunda şüphelilerden birinin bu usulün uygulanmasını kabul etmemesi hâlinde seri muhakeme usulü uygulanmaz.

(12) Seri muhakeme usulü, yaş küçüklüğü ve akıl hastalığı ile sağır ve dilsizlik hâllerinde uygulanmaz.

(13) Resmî mercilere beyan edilmiş olup da soruşturma dosyasında yer alan adreste bulunmama veya yurt dışında olma ya da başka bir nedenle şüpheliye ulaşılamaması hâlinde, seri muhakeme usulü uygulanmaz.

(14) Dokuzuncu fikra kapsamında Cumhuriyet savcısının talebi doğrultusunda mahkemece kurulan hükme 
uygulanması teklifinin yapılıp yapılmadığını, şüphelinin teklifi müdafi huzurunda kabul edip etmediğini ve fiilin TCMK m.250'de sayılan katalog suçlardan birine uygun olup olmadığını kontrol eder (TCMK m.250/9). Bu şartlar yerine gelmişse, mahkeme talepname doğrultusunda hüküm kurmak zorundadır (TCMK m.250/9). Mahkemenin talepnameyi başka bir nedenle reddetme veya Cumhuriyet savcısının belirlediği cezayı değiştirme yetkisi bulunmamaktadır.

TCMK m.250'de düzenlenen seri muhakeme usulü, soruşturma aşamasında uygulanan bir yöntemdir. Buna karşın AlCMK §257c'de düzenlenmiş olan hüküm anlaşması kovuşturma aşamasında uygulanmaktadır. Hüküm anlaşmasında, taraflara anlaşma teklif eden, delilleri takdir eden mahkemedir. Seri muhakeme usulünde ise, deliller mahkeme tarafindan değerlendirilmemekte, seri muhakeme usulü uygulanması teklifi mahkeme tarafindan değil, Cumhuriyet savcısı tarafindan yapılmaktadır. Mahkeme, yalnızca eylemin seri muhakeme kapsamında olup olmadığını, şüpheliye seri muhakeme usulü teklifi yapılıp yapılmadığını ve şüphelinin müdafi huzurunda özgür iradesiyle bu teklifi kabul edip etmediğini denetleyebilir (TCMK m.250/9). Seri muhakeme usulünde adli sicile işlenecek olan hükmü ${ }^{130}$ görünüşte mahkeme vermektedir, ancak hükmün içeriğini Cumhuriyet savcısı belirler. TCMK m.250'de öngörülen usul, özü itibariyle tez ve antitezin ortaya konup tartış1ldığ ve buradan bir sonuç çıkartılan klasik bir yargılama faaliyeti değildir. Hüküm anlaşmasında sürecin patronu mahkemeyken, seri muhakeme usulünde Cumhuriyet savcısıdır.

Seri muhakeme usulünde yargılamanın duruşma safhasından vazgeçilmekte ve duruşma yapılmadan hüküm aşamasına geçilmektedir. Söz konusu usulde iddianame düzenleme ve duruşma safhaları tamamen ortadan kaldırılmaktadır. İddianame düzenlenmediği için kovuşturma aşamasına geçilmemekte, şüpheliye sanık sıfatı verilmeden, hükümlü sıfatı verilmektedir. Seri muhakeme usulünde mahkeme, şüpheliyi suçla ilgili olarak sorguya çekemez, yalnızca müdafi huzurunda seri muhakeme usulü ile ilgili olarak dinleyebilir ${ }^{131}$. Mahkeme talepnamenin eksik olup olmadığını; eylemin seri muhakeme usulü kapsamında bir suç oluşturup oluşturmadığını; cezanın belirlenmesinde maddi hata yapılıp yapılmadığını; Cumhuriyet savcısı hükmün açıklanmasının geri bırakılması, cezanın seçenek yaptırıma çevrilmesi veya ertelenmesi kararı vermişse, bu kararlara ilişkin objektif koşulların gerçekleşip gerçekleşmediğini; hükmedilmesi talep edilen cezaya uygun bir güvenlik tedbiri belirleyip belirlemediğini; şüpheliye usulüne uygun teklif yapılıp yapılmadığını ve şüphelinin müdafi huzurunda, özgür iradesiyle teklifi kabul edip etmediğini kontrol eder (TCMK m.250/). Bu usul, mahkemenin maddi gerçeği ortaya çıkarma ödevi ve muhakemenin maddi gerçeğe ulaşma amacıyla bağdaşmamaktadır. Hüküm anlaşmasında ise, maddi gerçeğe ulaşma amacı, muhakemenin hızlı bir şekilde sona erdirilmesi amacının önüne geçmektedir. Bu nedenle, hüküm anlaşması mahkeme açısından mutlak bağlayıcı değildir (AlCMK §257c/4). Mahkeme maddi veya hukuki açıdan hükme etki edecek hususları gözden kaçırdığında veya bu hususlar sonradan ortaya çıktığında anlaşmadan cayabilmekte ve anlaşmadan bağımsız yepyeni bir hüküm kurabilmektedir.

Hüküm anlaşması üzerine yaptı̆̆ımız bu çalışma, gerekçedeki iddianın aksine TCMK m.250'de yer alan "seri muhakeme usulü” düzenlenirken, AlCMK §257c'nin örnek alınmadığını, iki kurum arasında benzerlik bulunmadığını ortaya koymuştur. Türk Ceza Muhakemesi Kanunu'nda yer alan seri muhakeme usulü (TCMK m.250), hüküm anlaşmasından ziyade Fransız ceza hukukunda uygulanmakta olan "suçunu kabul edenlerin yargılanmas,"132 usulüne benzemektedir. Fransız hukukunda uygulanan söz konusu usule göre; beş yıla kadar hapis cezası öngören suçlarla ilgili savcıyla şüpheli belirli bir yaptırım konusunda anlaşmaktadır. Mahkeme dışında geçekleşen bu anlaşma kamuya açık bir duruşmada mahkemenin onayına sunulmakta ve mahkeme tarafindan incelendikten sonra uygun bulunursa, onaylanmaktadır. Mahkeme onayıyla kamu davası düşmekte ve üzerinde savcıyla şüphelinin anlaştığı yaptırımın infazına geçilmektedir ${ }^{133}$. AlCMK $§ 257 \mathrm{c}$ 'de düzenlenmiş olan hüküm anlaşması hem TCMK m.250'de

itiraz edilebilir

(15) Bu maddenin uygulanmasına ilişkin usul ve esaslar Adalet Bakanlığ tarafından çıkarılan yönetmelikle belirleni

${ }^{130}$ Ceza Muhakemesinde Seri Muhakeme Yönetmeliği m.10/1, f.

${ }^{131}$ Ceza Muhakemesinde Seri Muhakeme Yönetmeliği m.13.

132 TAŞKIN, Mustafa, "Fransız ve Türk Hukukunda Suçunu Kabul Edenlerin Yargılanması”, THD, S.44, Nisan 2010, s.23.

${ }^{133}$ Fransız hukukunda uygulanmakta olan bu usulde mahkemenin, yaptığı inceleme neticesinde, savciyla şüphelinin üzerinde anlaştığı yaptırımı onaylama veya reddetme konusunda takdir yetkisi olduğu aktarılmaktadır. Mahkeme önerilen ve kabul edilen yaptırım üzerinde değişiklik yapamaz. Ancak mahkeme yaptığı incelemede, sanığın o suçu 
düzenlenmiş olan "seri muhakeme usulünden" hem de klasik ceza yargılaması ilkelerinin büyük bir kısmını devre dışı bırakan ${ }^{134}$ Fransız ceza hukukundaki "suçunu kabul edenlerin yargılanması usulünden" ${ }^{135}$ farklıdır.

\section{DEĞERLENDİRME VE SONUÇ}

Ceza muhakemesini hızlandırma çabaları ve bu yönde geliştirilen kurumlar tüm dünyada ciddi bir uygulama alanı bulmuştur. Klasik ceza muhakemesi usulünün uygulama alanı giderek daralmaktadır. Örneğin; Amerika ve İsviçre'de ceza uyuşmazlıklarının yalnızca \%10'luk bir kısmı normal ceza muhakemesi yöntemleriyle çözümlenmektedir. Kalan \%90’lık kısım ise, klasik ceza muhakemesi dışındaki usul ve yöntemlerle sonlandırılmaktadır. Japonya'da ise ceza uyuşmazlıklarının yaklaşık 3/4'ünde, "ceza kararnamesi” adlı bir kısa muhakeme usulü uygulanmaktadır ${ }^{136}$.

Alman ceza muhakemesi hukukunda hüküm anlaşması; zaman, maliyet, toplumsal ve hukuki barış açısından önemli avantajlar sağlamaktadır. Ancak, hüküm anlaşması ceza muhakemesinin temel ilkeleri açısından dikkatli uygulanması gereken bir kurumdur. Alman ceza muhakemesi hukukunda, maddi gerçeğe ulaşmak için hukuka uygun yollarla "re'sen araştırma" ilkesi geçerlidir. Savcılığın veya savunmanın getirdiği delillerden bağımsız olarak, maddi gerçeği ortaya çıkarmakla görevli olan mahkeme, kendiliğinden olgu ve delil araştırması yapabilir ${ }^{137}$. Buna karşın Anglo-Amerikan hukuk sistemi taraf muhakemesi şeklinde yürür ve mahkeme, tarafların önüne getirdiği delillerle bağlıdır ${ }^{138}$. Taraf muhakemesi şeklinde yürüyen bir ceza muhakemesi sisteminde, taraflar kendi aralarında anlaşabilir. Buna karşın maddi gerçeğe ulaşmak için re'sen araştırma ve kovuşturmaya devam etme mecburiyetini benimsemiş bir hukuk sistemiyle, hüküm anlaşmasının bağdaşması kolay değildir. Bu düşünce, Alman ceza hukukunda hüküm anlaşmasına karşı çıkılmasının asıl nedenidir. Hüküm anlaşmasının, hukuk devleti ilkesine dayanan klasik ceza muhakemesine zarar vermesinden endişe edilmektedir ${ }^{139}$.

Hüküm anlaşmasının, duruşmaya hakim olan alenilik, delillerin doğrudan doğruya değerlendirilmesi ve savcılığın açmış olduğu kamu davasını takip etme mecburiyeti (kovuşturma mecburiyeti) ilkelerine aykırılık teşkil edebileceğine ilişkin görüşlerde ${ }^{140}$ haklılık payı bulunmaktadır. Ancak Federal Alman Mahkemesi kararlarında, hüküm anlaşmasının duruşma salonunda, herkesin gözü önünde yapılması ve müzakerelerin duruşma tutanağına geçirilmesi gerektiğine açıkça işaret ederek, alenilik ilkesine; sanığın süreç hakkında doğru ve ayrıntılı bir şekilde aydınlatılması ve mahkemenin sanığın ikrarının gerçeğe uygun olup olmadığını denetlemesi gerektiğine vurgu yaparak, maddi gerçeğin araştırılması ilkesine uygun bir içtihat oluşturmaya çalışmaktadır.

Hüküm anlaşmasında, muhakemenin soruşturma ve kovuşturma aşamaları muhafaza edilmektedir. Muhakemenin duruşma safhası kısaltılarak, kovuşturma aşaması daha hızlı sonlandırılmaktadır. Bununla birlikte, sanığın kusuru ve suçun sabit olup olmadığı konusundaki nihai kararı, hakim duruşmada ortaya konan delillere göre vicdani kanaatiyle vermektedir. Yargılama dosya üzerinden değil, duruşma yapılarak yapılmaktadır. AlCMK §257c/3'de mahkemenin, somut olayın bütün özelliklerini ve cezanın belirlenmesine ilişkin genel kuralları dikkate alarak, teklif edilen cezanın alt ve üst sınırını belirleyeceği düzenlenmiştir. Taraflar özgür iradeleriyle, mahkemenin teklifini kabul ederse, mahkeme anlaşmaya uygun bir hüküm kurmaktadır. Hüküm anlaşmasının şartlarını, muhakeme süjeleri değil mahkeme belirlemektedir. Ayrıca mahkeme, önceden var olan ve hükme etki eden bazı hususları gözden kaçırdığında veya

işlemediği kanaatine ulaşırsa veya suçu işlediğinden emin olmakla birlikte, önerilen yaptırımın işlenen suçla orantılı olmadığı kanaatine varırsa, anlaşmayı onaylamaz. Bkz. TAŞKIN, s.37.

134 TASKIN, s.23.

${ }^{135} \mathrm{Bu}$ usulde de tıpkı seri muhakemede (TCMK m.250) olduğu gibi bir iddianame düzenlenip kamu davası açılmadan, savcıyla şüpheli arasında soruşturma aşamasında yapılan yaptırım sözleşmesi mahkemenin onayına sunulmaktadır. Mahkeme önünde yapılan işlem aslında bir muhakeme değil, sadece yaptırım anlaşmasının sonucunun kaydedilmesi ve gerekçeli mahkeme kararı haline getirilmesidir. Mahkeme, anlaşmayı ret veya kabulden ibaret sınırlı bir yetkiye sahiptir. Bkz. TAŞKIN, s.36.

${ }^{136}$ GOEHLER, Johanna, "Strafverfahren ohne Hauptverhandlung im Rechtsvergleich- Ein Bericht über die 36. Tagung der Gesellschaft für Rechtsvergleichung aus strafrechtlicher Perspektive”, in: ZStW 2018 (130), s.521.

${ }^{137}$ KREY/HEINRICH, kn. 566-568.

138 ÖZTÜRK VE DİĞERLERİ, s.85.

${ }^{139}$ ROXIN/ACHENBACH/JAEGER/HEINRICH, s. 152.

${ }^{140} \mathrm{KREY} / \mathrm{HEINRICH}, \mathrm{kn} .1510,1511$. 
bu hususlar sonradan ortaya çıktığında, anlaşmadan cayabilmektedir. AlCMK §257c/4'de yapılan açık düzenlemeyle anlaşmanın, maddi gerçeğin araştırılması ilkesinin önüne geçmesine müsaade edilmemiştir. Hüküm anlaşması tamamen gönüllü ve iradi bir süreç olarak düzenlendiğinden, sanığın anlaşmadan cayması ise her zaman mümkündür.

AlCMK §257c uygulandığında hüküm, mahkeme tarafindan vicdani kanaatine göre verilmektedir. Bu usulde, mahkemenin hükümle ilgili yetkileri kısmen de olsa savcılık gibi başka bir mercie devredilmemekte, mahkeme kısa bir yargılama yaparak hüküm kurmaktadır. Bu açıdan hüküm anlaşması, TCMK m.250'de düzenlenen ve cezanın belirlenmesini Cumhuriyet savcısına bırakan, mahkemenin muhakeme sürecindeki rolünü, savcının belirlediği cezayı hükme çevirmeye indirgeyen, muhakemenin kovuşturma aşamasını atlayarak, soruşturma aşamasından doğrudan hüküm verme aşamasına geçen "seri muhakeme usulünden" ayrılmaktadır. Bu açıdan hüküm anlaşmasıyla TCMK m.250'de yer alan "seri muhakeme usulü" arasında önemli farklar bulunmaktadir.

Hüküm anlaşması konusunda işaret edilmesi gereken bir diğer husus da AlCMK §257c'nin oldukça dikkatli formüle edilmiş olmasına rağmen, bazı yasal boşluklar içerdiğidir. Kanun iştirak halinde işlenen suçlarda, hüküm anlaşmasının yapılıp yapılamayacağı veya nasıl yapılacağı konusunda sessiz kalmıştır. Suç ortaklarından bazılarının anlaşmayı kabul edip, diğerlerinin reddetmesi durumunda, hüküm anlaşmasının nasıl uygulanacağı belirsizdir ${ }^{141}$.

Benzer şekilde kanun, anlaşma yapıldıktan sonra, ancak henüz hüküm kesinleşmeden önce istinaf veya temyiz süresi içinde anlaşmadan vazgeçilmesi durumunda, nasıl hareket edileceği sorusuna da bir cevap vermemektedir ${ }^{142}$.

Hüküm anlaşmasına ilişkin kötü uygulamalar, öğretinin kuruma karşı mesafeli yaklaşmasının bir diğer nedenidir. Öğretideki en önemli kaygılardan biri aleniyet ilkesinin ihlal edilmesi ve müzakerelerin tutanağa geçirilmesinde özenli davranılmamasıdır ${ }^{143}$. Müzakerelere ilişkin duruşma tutanakları ne kadar ayrıntılı ve açık tutulursa, ihlallerin önüne o kadar kolay geçilir ve kuruma olan güven o oranda $\operatorname{artar}^{144}$. Usulüne uygun tutulan duruşma tutanakları, üst derece mahkemeleri tarafından yapılacak kanun yolu denetimi açısından da vazgeçilmezdir. Mahkemelerden, zamanla hüküm anlaşmasını kanunda düzenlendiği şekliyle uygulamayı alışkanlık haline getirip, hukuka aykırı ceza pazarlığı alışkanlıklarından vazgeçmeleri beklenmektedir ${ }^{145}$.

Alman kanun koyucu öğretideki tereddütlere ve eleştirilere rağmen, suç politikasına ilişkin bir tercihte bulunmuş ve "hüküm anlaşmasını" yasal zemine kavuşturmuştur. Mahkemelerin ağır iş yükü ve bazı suçlarla ilgili yargılamaların kısaltılmasındaki bireysel ve kamusal yarar, muhakemeyi hızlandıran kurumları vazgeçilmez kılmaktadır.

Türkiye'de de yargının ağır iş yükü baskısı altında olması ve adaletin gecikmesinin toplumun her kesimini rahatsız etmesi, muhakemeyi hızlandıran yeni kurumlara ihtiyaç olduğunu göstermektedir. Öğretide getirilen eleştiriler dikkate alınır ve ceza muhakemesi hukukunun temel ilkeleriyle ilgili endişeler giderilirse, "hüküm anlaşması" ülkemizde yapılacak yeni düzenlemelere örnek teşkil edebilir.

\footnotetext{
${ }^{141}$ ROTHE/SZALAI, NJOZ 2013, s.1806.

142 ROTHE/SZALAI, NJOZ 2013, s.1806.

${ }^{143}$ FISCHER, ZRP 2010, s.250.

${ }^{144}$ ROTHE/SZALAI, NJOZ 2013, s.1806.

${ }^{145}$ FISCHER, ZRP 2010, s.251.
} 


\section{KAYNAKÇA}

AMBOS, Kai/ZIEHN, Pamela: Strafprozessordnung, Kommentar, Herausgegeben von Radtke, Henning/Hohmann Olaf, München 2011.

BEULKE, Werner/SWOBODA, Sabine: Strafprozessrecht, 14. Aufl., Heidelberg 2018.

DEITERS, Mark: “Abgekürzte Strafverfahren”, ZStW 2018 (130), s.491-512.

DEAL, Detlef: "Mauschelhausen, Der strafprozessuale Vergleich", StV 1982, H. 11, s.545-552.

DUTTGE, Gunnar: "Die Urteilabsprachen als Signum einer rechtlichen Steuerungskriese", in: Festschrift für Bernd Schnemann zum 70. Geburtstag am 1. Nowember 2014, Berlin, Boston 2014, s.877-889.

FISCHER, Thomas: "Ein Jahr Absprache-Regelung Praktische Erfahrungen und gesetzlicher Ergänzungsbedarf”, in ZRP 2010, s.249-251.

GOEHLER, Johanna: "Strafverfahren ohne Hauptverhandlung im Rechtsvergleich- Ein Bericht über die 36. Tagung der Gesellschaft für Rechtsvergleichung aus strafrechtlicher Perspektive", in: ZStW 2018 (130), s.513-525.

GOETTGEN, Martin: Prozessökonomische Alternativen zur Verständigung im Strafverfahren, Berlin 2019.

KUHNE, Hans-Heiner: Strafprozessrecht- Eine systematische Darstellung des deutschen und europäischen Strafverfahrensrechts, 9. Aufl., Heidelberg 2015.

MEYER-GOßNER, Lutz/SCHMITT, Bertram: Becksche Kurz Kommentare, Strafprozessordnung, 60. Aufl., München 2017.

MURMANN, Uwe: "Reform ohne Wiederkehr?- Die gesetzliche Regelung der Absprachen im Strafverfahren", in: ZIS 10/2009, s.526-538.

KREY, Volker/HEINRICH, Manfred: Deutsches Strafverfahrensrecht, 2. Aufl., Stuttgart 2019.

ÖZBEK, Veli Özer/DOĞAN, Koray/BACAKSIZ, Pınar, Ceza Muhakemesi Hukuku, 12. Baskı, Ankara Ağustos 2019.

ÖZTÜRK, Bahri/TEZCAN, Durmuş/ERDEM, Mustafa Ruhan/SIRMA GEZER, Özge/

SAYGILAR KIRIT, Yasemin F./ALAN AKCAN, Esra/ÖZAYDIN, Özdem/ERDEN TÜTÜNCÜ, Efser/ALTINOK VİLLEMIN, Derya/TOK, Mehmet Can: Nazari ve Uygulamalı Ceza Muhakemesi Hukuku, 13. Baskı, Ankara Eylül 2019.

ROTHE, Manuel/SZALAI, Stephan: “Der Deal im Strafprozess- Sunlicht is the best disinfectant?", in: NJOZ 2013, s.1801-1807.

ROXIN, Claus/ACHENBACH, Hans/JAEGER, Christian/HEINRICH, Manfred: Strafprozessrecht, 17. Aufl, München 2019.

ROENNAU, Thomas: "Grundwissen: Strafprozessrecht: Verständigug im Strafverfahren”, JuS 2018, s.114-118.

TAŞKIN, Mustafa: "Fransız ve Türk Hukukunda Suçunu Kabul Edenlerin Yargılanması”, THD, S.44, Nisan 2010, s.23-48.

TSUJIMOTO, Norio: "Eine inhaltliche Analyse der Verständigung im deutschen Strafprozess aus der Perspektive eines Aussenstehenden”, in: ZIS 12/2012, s.612-622

UĞUR, Hüsamettin: "Ceza Muhakemesinde Kovuşturma Mecburiyeti İlkesinden Maslahata Uygunluk İlkesine", TBBD, S.73, Y. 2007, s.256-288.

VOLK, Klaus/ENGLAENDER, Armin: Grundkurs StPO, 9. Aufl., München 2018, §30.

YENISEY, Feridun/NUHOĞLU, Ayşe: Ceza Muhakemesi Hukuku, 7. Baskı, Ankara Ağustos 2019. 